\title{
Framework for the promotion of accountability in the Social Economy: the specific case of Private Social Solidarity Institutions
}

\author{
Augusta Ferreira \\ Higher Institute for Accountancy and Administration of University of Aveiro, \\ Center for Research in Accounting and Taxation of the Polytechnic Institute of Cávado and Ave \\ augusta.ferreira@ua.pt

\section{Carlos Santos} \\ Higher Institute for Accountancy and Administration of University of Aveiro \\ Center for Research in Accounting and Taxation of the Polytechnic Institute of Cávado and Ave \\ carlos.santos@ua.pt

\section{Helena Inácio} \\ Higher Institute for Accountancy and Administration of University of Aveiro \\ Research Unit on Governance, Competitiveness and Public Policies, University of Aveiro \\ helena.inacio@ua.pt
}

\begin{abstract}
Alberto J. Costa
Higher Institute for Accountancy and Administration of University of Aveiro Research Unit on Governance, Competitiveness and Public Policies, University of Aveiro alberto.costa@ua.pt
\end{abstract}

\section{Ana Maria Bandeira}

Higher Institute for Accountancy and Administration of Porto, Polytechnic of Porto

Centre for Organizational and Social Studies of the Polytechnic of Porto bandeira@iscap.ipp.pt

\section{Brízida Tomé}

Centre for Organizational and Social Studies of the Polytechnic of Porto brizida.tome@gmail.com

\section{Carla Joaquim}

Polytechnic Institute of Tomar

carlamfreitas@ua.pt

Cristina Góis

ISCAC Coimbra Business School of the Polytechnic of Coimbra crgois@sapo.pt

\section{Denise Curi}

Higher Institute for Accountancy and Administration of University of Aveiro denpec11@gmail.com

\section{Deolinda Meira}

Higher Institute for Accountancy and Administration of Porto, Polytechnic of Porto Centre for Organizational and Social Studies of the Polytechnic of Porto meira@iscap.ipp.pt

\section{Graça Azevedo}

Higher Institute for Accountancy and Administration of University of Aveiro Center for Research in Accounting and Taxation of the Polytechnic Institute of Cávado and Ave graca.azevedo@ua.pt 


\author{
Mafalda Jesus \\ National Confederation of Solidarity Institutions \\ mj.tecnico@cnis.pt \\ Maria Goreti Teixeira \\ National Confederation of Solidarity Institutions \\ maria.goreti.teixeira.1@gmail.com \\ Patrícia Monteiro \\ National Confederation of Solidarity Institutions \\ pm.tecnico@cnis.pt \\ Rúben Duarte \\ Higher Institute for Accountancy and Administration of University of Aveiro \\ rubenduarte@ua.pt \\ Rui Pedro Marques \\ Higher Institute for Accountancy and Administration of University of Aveiro \\ Algorithmic Research Centre of University of Minho \\ ruimarque@ua.pt
}

\begin{abstract}
Given the extreme importance of improving the accountability of Private Social Solidarity Institutions (IPSS), both for reasons of legal compliance (hard law) and for reasons of improving legitimacy and notoriety among their stakeholders (soft law), this paper aims to present a framework designed under a more comprehensive research project, for the assessment of IPSS accountability and, consequently, its improvement. This study also present results of the indicators conceived, identifying the main trends of the framework dimensions and subdimensions from a pilot test for the years 2018, 2019 and 2020 in Portugal.

Given the results, we believe that the framework designed answers the research question: How to promote accountability (social, financial and economic) in the social economy sector, in particular: the case of the IPSS?, however, as this is an exploratory article, it incorporates the limitation that this is a pilot test with only 7 entities.
\end{abstract}

KEY WORDS: Accountability; Governance; IPSS; Indicators; Sustainability; Transparency.

INTRODUCTION 
The great demands of stakeholders and the high importance of Private Social Solidarity Institutions (IPSS) ${ }^{1}$ in the Portuguese socio-economic panorama make imperative the transparency and increased accountability (social, financial and economic) of these institutions (Ferreira, Santos \& Curi, 2019). In the same sense Tomé, Bandeira, Azevedo \& Costa (2019) reinforce that it is necessary to promote the evaluation of results and their disclosure to help to increase their accountability. Decree-Law no.172-A/2014 establishes a financial supervision model, applicable to IPSS, based on demanding imperative rules, in view to increasing the accountability of the management of these entities, placing strong pressure for greater accountability (social and corporate responsibility of IPSS' managers) towards their members, funders, users and citizens in general.

There is also a growing need to disseminate good practices and the social impact these institutions have on the community.

In that context, the project named "TheoFrameAccountability"2 (TFA) aims to answer the following research question: How to promote accountability (social, financial and economic) in the social economy sector, in particular: the case of the IPSS? One of its objectives is to conceptualise a framework that allows stakeholders to evaluate the performance of the IPSS, and to allow the IPSS to make a self-evaluation of their performance and accountability, meeting the growing need for dissemination of good practices and the social impact they have on the community in which they operate.

To this end, a framework of indicators was developed that provides stakeholders with an assessment of the accountability of the IPSS in complying with the principles inherent to the guarantee of sustainability of these organisations (Ferreira, Santos \& Curi, 2019).

An extensive review of the literature on Accountability, Sustainability, Transparency, Governance, Social Economy and IPSS allowed us to conclude that the assessment of accountability involves, in addition to the economic and financial dimensions, further dimensions that meet the social and environmental aspects, each one presenting several subdimensions. (Bagnoli and Megali, 2011; Sanford, 2011; Arena, Azzone, and Bengo, 2015; Crucke and Decramer, 2016; Tomé, Meira, and Bandeira, 2016; Gibbons and Jacob, 2018).

Indicators were considered in each of the subdimensions. These indicators aim to measure important aspects such as: how the entity defines its mission and strategic objectives, its

\footnotetext{
${ }^{1}$ Acronym in portuguese standing for Instituições Particulares de Solidariedade Social.

${ }^{2}$ Theoretical framework for promotion of accountability in the social economy sector: the IPSS case.
} 
governance model and transparency; how entities deal with their responsibilities in society, including relations with stakeholders (beneficiaries, employees, suppliers, State, volunteers, etc.); economic efficiency and the effort to achieve economic balance; how entities relate to the community in which they are inserted (namely through partnerships, employees, suppliers, State, volunteers, etc.); the way entities relate to the community in which they are inserted (namely through the creation of partnerships, social investments and patronage); energy efficiency and relationship with the environment; and the way in which the entity adapts to technological evolution, through the adoption and acceptance of emerging technologies both in the support of its operational activity and in its own promotion to the outside.

After designing the framework, the next step was the validation of the framework using the Focus Group methodology.

In this study we propose to present the framework with the indicators conceived, identifying the main trends of the framework dimensions and sub-dimensions from a pilot test. This test was carried out with 7 IPSS who completed the questionnaires made available through the specific platform created by the TFA project and for the years 2018, 2019 and 2020.

The study carried out aimed to identify the main trends, in an analysis by different dimensions, and to analyze the adequacy of the first results in relation to the expectations formulated on the basis of the literature review previously analyzed.

This paper is organized as follows: after this first introductory section the literature review is present in the second section; the third section presents the research methodology, the framework design is shown in section fourth, and the results of the pilot test are presented and discussed in section fifth and the sixth section presents the final considerations.

\section{LITERATURE REVIEW}

Several studies reveal that stakeholders are increasingly demanding higher levels of information, which is also valid for all other sectors of the economy, a fact that cannot be underestimated by non-profit organisations, namely the IPSS, and as such, the accountability practices pursued must be adapted to those entities. (Conroy, 2005; Zainon et al., 2014 a) e 2014b).

In fact, the IPSS, which are the focus of this study, should verify whether the accountability practice adopted meets the requirements of their stakeholders, as it may affect the effectiveness 
and fulfilment of their mission (Costa, Ramus \& Andreaus, 2011). These authors highlight the prevalence given to the economic-financial dimension in detriment of other dimensions, which seems contradictory when these organisations have as their main purpose the pursuit of the general interest. The difficulty seems to be, on the one hand, in the lack of objective definition of quantifiable variables suitable for assessing the impact of the activities developed by the social economy entities, and on the other hand, in the pressure brought to bear by funders and regulatory and supervisory bodies, namely the State.

We cannot fail to highlight the demands placed on the IPSS, especially with the entry into force of the revised IPSS' Statute (Decree Law 172-A/2014, of 14 November). This Statute establishes a new model for the financial supervision of IPSS, based on denser and demanding mandatory rules in order to increase transparency in the management and accountability of these entities (Tomé, Meira \& Bandeira, 2016).

The concept of accountability, initially linked to accounting, has evolved to a quite different reality. Accountability does not refer only to accounting information, but to the actor's responsibility for all decisions important/relevant to stakeholders, who may demand explanations and justifications (Bovens, 2006). Also, according to this author, the term accountability is increasingly used because it conveys an image of transparency and trust, applicable to any sector, be it public, private or social economy sector.

According to Bovens (2006), accountability is used as a way of positively qualifying a state of affairs or the performance of an actor. It is close to responsiveness and sense of responsibility, to the will to act in a transparent, fair and equitable way, but it also refers to concrete accountability practices.

In the case of IPSS, Connolly \& Kelly (2011) emphasize the importance that the reporting of these organisations becomes more reliable and transparent, so that with this accounting information of higher quality, one can give visibility to the resources mostly granted by the State, as well as the activities and objectives of the institutions, increasing their notoriety and legitimacy, generating greater confidence to stakeholders. However, the accountability of these institutions goes beyond accounting information, since the decision-making process includes aspects that go beyond them, simultaneously making the disclosure process more complex, with factors that are more difficult to quantify, such as the social impacts of their activities (Connolly and Kelly, 2011). The measurement of this kind of impact generated by an IPSS in the community, normally based on non-accounting information, requires the transformation of 
qualitative information into useful indicators for all stakeholders (Aimers and Walker, 2008a). For Choudhoury and Ahmed (2002), accountability was focused, until a few decades ago, on internal controls and auditing, monitoring, evaluation and compliance with rules and regulations. We are now witnessing a paradigm shift: from simple financial accounting to performance auditing and public accountability, i.e., towards all stakeholders.

Becker (2018) points out the trend of non-profit organizations to adopt new modalities of accountability, which go beyond the minimum legally imposed requirements. In this way, they will have managed to increase their transparency and implement good governance, simultaneously resulting in increased credibility, reputation and capacity to attract funders.

From a conceptual point of view, accountability is often used as a synonym for evaluation, and confused with concepts such as responsiveness, responsibility and effectiveness. In an attempt to analyse a restricted definition of accountability, Bovens (2006) emphasises the existence of a series of dimensions that are associated with it, both from the relational point of view and in terms of the objectives underlying the various areas of governance. Furthermore, accountability is very often associated with good governance or socially responsible behaviour, a very relevant factor as far as the IPSS are concerned.

Tomé, Bandeira, Azevedo \& Costa (2019) draw particular attention to the case of IPSS, to whom more and greater challenges are posed by their stakeholders in general, namely: (i) by the State, given the preferential partnership it maintains with these institutions, in addition to its role as regulator; (ii) by private for-profit companies, whose corporate social responsibility programmes bring them into regular contact with these organisations; (iii) by the need for these non-profit entities to become more efficient and effective, open to internal and external reality, facilitating access and perception of their socially responsible behaviour, credibility and transparency at all levels, (economic, social and environmental). Fulfilment of all these requirements implies the effective planning and development of activities, the promotion of the evaluation of results and their disclosure, whether in compliance with legal obligations or other parameters voluntarily expressed but that may help increase their accountability.

All these interpretations suggest the diversity of dimensions in which accountability is established and which characterise institutions and the way in which they interact with their internal and external environments.

Internally and from their genesis, the IPSS should pay special attention to their organisational structure, incorporating new accountability practice mechanisms as a means of increasing 
knowledge and appropriate forms of governance, promoting their sustainable development (Rotheroe and Richards, 2007). Other studies analyse the impact of organisational characteristics on the accountability practices of non-profit organisations, establishing relationships between organisational profile and the level of accountability (Azman, Arshad and Bakar, 2015; Bakar, Arshad, Azman and Omar, 2013; Bakar, Asrhad, Azman and Omar, 2014).

Also, according to Arshad, Bakar, Thani and Omar (2013) the composition of management bodies influences accountability practices, whose instruments and associated activities may become, in turn, a useful contribution to the current governance systems, but with effects not yet fully known (Becker, 2018). Also, of particular interest is a study lead by Atan, Alam and Said (2017) in which the authors assessed the organisational integrity of non-profit organisations and concluded that this contributes significantly to the accountability practices adopted by them.

Equally important is the adequacy of the products and services provided to the community. The IPSS cover a broad range of services, particularly in the area of social services, not neglecting education, health, sports and culture, among others, meeting the specific needs of their community, a fact that also increases the imperativeness of accountability (Barret, 2001).

With regard to the external environment, of particular importance is the fact that the sustainable development of the IPSS is directly linked to the importance of including stakeholders at all levels of decision-making, improving the practice of accountability, from the rendering of accounts itself, to its justification and influence on the level of positive perception (Rotheroe and Richards, 2007). In the opinion of Aimers \& Walker (2008b) the partnerships between social economy organisations and the State could lead to difficulties in their relations with the community, as result they propose several models for strengthening the integration of these institutions in their communities, through accountability mechanisms, leading to an increase in their accountability.

Awio, Northcott and Lawrence (2011) add that networks and cooperative actions within groups contribute to improving accountability, in the same way that voluntarism and reciprocity work to enhance efficiency and accountability, through donations of time, money and material contributions from the community. Participatory monitoring and evaluation by society was the subject of study by Sangole, Kaaria, Njuki, Lewa and Mapila (2014) who concluded that these actions strengthen social capital while affecting the community's perception of the organisation's performance, impacting on its accountability. 
In order to improve the sustainable development of social economy organisations on the one hand, and increase stakeholder confidence on the other, the need to combine modernisation and accountability was documented by Santos, Ferreira, Marques, Azevedo \& Inácio (2019). They also highlight the importance of designing quality internal control mechanisms, as a guarantee of good accountability practices, alignment and integration of all stakeholders, raising performance and trust levels, thus resulting not only in individual growth but also in community development. The impact in terms of contribution to the pursuit of the Sustainable Development Goals (SDGs) should be as well highlighted, with a visible result in community terms, but often difficult to measure and adequately perceived.

However, according to Marques, Santos \& Duarte (2019), the assessment of accountability is still limited due to the absence of a framework that adequately implements accountability practices in all its dimensions. These authors advocate that the use of new information and communication technologies (ICTs) can contribute to the modernisation of the sector, through the creation of institutional websites, where institutions can disclose financial and non-financial information, allowing their stakeholders to assess their mode of operation and performance. The motivation of stakeholders may be improved as the websites become better and more proactive, and both circumstances will contribute to increase the legitimacy and notoriety of these institutions, with consequent advantages at all levels.

All these concerns have been motivating researchers to develop frameworks that enable the assessment of the accountability of social economy (SE) entities. Bagnoli and Megali (2011), based on the production process, propose a framework based on three dimensions. The first dimension is economic and financial performance - which aims, through the annual accounts, to assess economic efficiency and financial balance. The second is social effectiveness - which aims to assess the capacity to achieve goals and implement strategies using resources in a socially responsible way. This dimension should include indicators related to inputs (resources that contribute to the activities developed), outputs (activities carried out to achieve the mission and direct and accountable goods/services obtained through the activities carried out), results (benefits or impact for the intended beneficiaries), and impact (consequences of the activity for the community at large). The third dimension is that of institutional legitimacy - which involves verifying that the organisation has respected its "rules" (statute, mission, action program) and the legal norms applicable to its legal form. 
The idea that at the basis of social entrepreneurship lies the concept of social benefit is defended by Arena, Azzone, \& Bengo (2015), for whom the ultimate goal for non-profit organisations, becomes the actual "business idea" that needs to be explored, managed and realized. In this sense, and based on an extensive literature review, the authors propose a framework, called Performance Model System (PMS), which is structured into four dimensions: (1) financial sustainability (fundamental to ensure service delivery); (2) efficiency (associated with the relationship between material and human resources used and services provided); (3) effectiveness (associated with the characteristics of the output) and the (4) impact (associated with the outcome - a result measure related to the effects of "production" in the long term).

The effectiveness dimension, closely following Bagnoli and Megali (2011), was divided into management effectiveness, related to management strategy and the achievement of objectives, and social effectiveness which concerns the relationship between the non-profit organisation and its stakeholders, and which measures the organisation's capacity to meet the needs of its target community by means of the production of goods and services. Due to the importance of this dimension in the social economy sector, the authors divide the social effectiveness dimension into four sub-dimensions: equity (the ability to ensure access to products and services for vulnerable people); involvement (the ability to ensure the participation of relevant stakeholders in the decision-making process) and communication and transparency (the ability to inform stakeholders about the organisation's activities).

In the impact dimension, considering the particularities of non-profit organisations, the authors advocate that one must measure the coherence between the social mission and results. In this sense, the coherence should be evaluated via the connection between the resources employed/used/consumed (inputs), the products/services produced (outputs) and the results achieved (outcomes) that must be consistent with the organization's mission. In this way they consider three further subdimensions: resource value (the resources used to produce goods or services must be consistent with the organisation's mission); product/service value (the product/service must be consistent with the expected social value of the organisation); outcome value (the final impact of the product or service produced must meet the needs for which the organisation works).

Based on the framework presented by Sanford (2011), Gibbons \& Jacob (2018) propose an adaptation that is structured into five dimensions: (1) beneficiaries; (2) cocreators; (3) land/humanity; (4) community and (5) investors/financiers. The beneficiaries are those for 
whom programmes and services are provided (delivered), i.e. stakeholders; the cocreators are those with whom nonprofit organisations have partnerships and may include volunteers, staff, partner organisations and other stakeholders; land/humanity is the crucial point of the framework as the relationship with the earth is applicable to sustainability in any organisation, including nonprofit organisations; community refers to how an organisation's actions affect the community, the local perspective and the social context in which they operate; the investors/financiers are funders, contributors, donors, foundations and board members, without whom non-profit organisations could not achieve their mission.

Taking into consideration the particularities of non-profit organizations, Crucke and Decramer (2016) propose a performance measurement instrument sustained in the reliable, valid, and standardized assessment of organizational performance building a framework based on five dimensions: (1) economic - the economic performance is related to the economic conditions that underpin a strong financial position, which is important for the viability of the organisations. As such, the focus is not on the financial indicators reported in the annual financial reporting, but on the economic indicators that influence these financial indicators; (2) environmental - is focused on the efforts that organisations make to protect nature; (3) human - refers to the relationship of the organisation with its workforce; (4) community - refers to the manner in which organisations handle their responsibilities in society, including relationships with dominant stakeholders: beneficiaries of the social mission and customers, paying for the products and services delivered; and (5) governance - that refers to "systems and processes concerned with ensuring the overall direction, control and accountability of an organisation". The governance performance is a specific performance domain, as good governance practices are expected to have a positive impact on organizational decision making, positively influencing the other performance domains of the organization. When developing this tool, the authors considered that performance is multidimensional and that when assessing performance, inputs, activities, and outputs should be considered, but not their impact (outcomes). In this decision they took into consideration Ebrahim and Rangan's (2010) arguments that the conviction to consider outcomes and impacts would be an impediment to developing an adequate tool for social enterprises with diverse activities. For the Portuguese case Tomé, Meira, \& Bandeira (2016) propose a framework organised into the following five categories: (1) human resources; (2) products and services; (3) sustainability; (4) relationship with the community and (5) environmental. 
Given that many social economy organisations are evaluated by civil society, by the State or by their patrons and donors, there is a need for the institution to communicate its social effectiveness, herein understood as the ability to attain goals and implement strategies utilizing resources in a socially responsible way (Bagnoli \& Megali, 2011). Thus, as of the Triple Bottom Line (TBL) concept (Elkington, 1994; 1999) some authors developed frameworks with views to providing a tool to evaluate the accountability of non-profit organisations, observing not only the economic outcome of their activities but also their social and environmental results. However, studies conducted in the social economy field add other concerns beyond the three pillars proposed by the TBL, such as: institutional legitimacy (Bagnoli \& Megali, 2011), community and governance (Crucke \& Decramer, 2016). We are thus led to argue that the TBL is insufficient to communicate, enable understanding and raise awareness among the different stakeholders of social economy entities.

\section{Research Methodology}

The framework proposed in this study resulted from the combination of a set of methodologies which include: literature review, fieldwork and focus group.

The first stage consisted of an extensive literature review which included the themes of the social economy, IPSS, accountability, governance, sustainability and indicators. This literature review enabled the preparation of the fieldwork, which took place between March and July 2019, with the aim of getting to know the IPSS and the environment in which they develop their activity (Markham, 2013) as well as designing the framework.

The second stage consisted of conducting the fieldwork which was planned as suggested by Feldman (2019) and Jacob \& Furgerson (2012). Since conducting the fieldwork would not be feasible with all the entities in the population, 5358 IPSS at the time of the study, a representative sample of the study population was defined adopting a confidence level of $90 \%$ and a margin of error of $10 \%$, which resulted in a number of 67 IPSS. The 67 IPSS were randomly selected within each stratum, i.e. legal nature and geographical area. Despite the effort made to contact, visit and conduct the interview in the IPSS selected for the sample, only 31 interviews were conducted, up to July 2019. Content analysis of the resulting reports served as the basis for the construction of the framework and respective indicators, which was considered as the third stage.

For the validation of the framework and its indicators, the fourth stage, the focus group methodology was used, which is considered to be the most appropriate methodology for 
qualitative research studies. Considering the characteristics of this methodology, the focus group took into consideration the type of participants and their particularities, as well as an adequate moderation focused on the objectives to be achieved (Krueger \& Casey, 2009). The focus group gathered 49 participants selected according to their involvement with the object of analysis (IPSS), their practical but also theoretical knowledge. After a detailed assessment of the comments obtained from the focus group, the framework was further refined.

In the fifth stage, the questionnaire was developed to collect the data required to compute the indicators. In May 2020, the questionnaire was finalised and submitted to a pre-test in which ten experts from the academic and professional field participated. This analysis resulted in the final adjustments that allowed concluding the questionnaire to be submitted.

Finally, in the sixth stage, a pilot test was carried out to test the framework's output, allowing on the one hand, to adjust some inconsistency in the indicator calculations and, on the other hand, to analyse the results of the indicators. This process aims to assess whether the framework meets its initially defined objectives. The first 7 IPSS that completed the questionnaires for the years 2018, 2019 and 2020 were considered for the pilot test.

\section{Framework Design}

Based on the literature review, we found that TBL concept (Elkington, 1994; 1999), is the base for several authors presented diversified proposals for the design of appropriate frameworks to evaluate the accountability of non-profit organizations, considering the social and environmental dimensions in addition to the economic result. (Bagnoli and Megali, 2011; Sanford, 2011; Arena, Azzone, and Bengo, 2015; Crucke and Decramer, 2016; Tomé, Meira, and Bandeira, 2016; Gibbons and Jacob, 2018). However, aspects such as community and governance were emphasised as being of extreme importance to facilitate the alignment with non-profit organization stakeholders, which in the opinion of Ferreira, Santos \& Curi (2019) denoted the TBL's insufficiency to this effect. In their search to find a solution to this deficiency, these authors proceeded in parallel with the analysis of the social economy entities' production process and arrived at an extension of the dimensions corresponding to the various steps of this process which, completed with views of the organizational architecture, led to a framework organized according to the six-tuplet bottom line (SBL) concept with the following dimensions: Purpose; Partners (extended people concept); Profit; Proximity; Planet and Progress (Figure 1). 
Figure 1 - Combination of SBL dimensions with production process and enterprise architecture

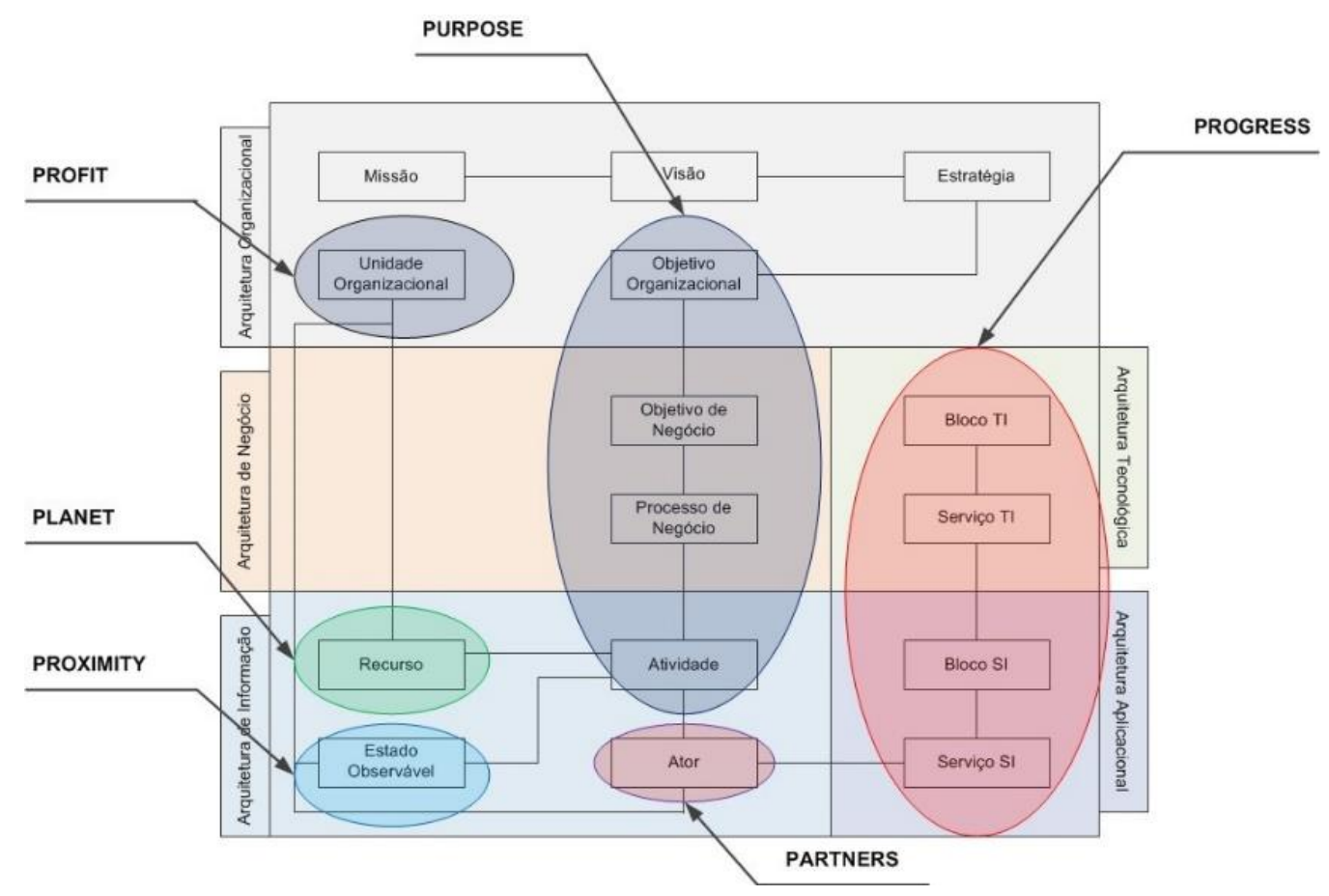

Source: Ferreira, Santos \& Curi (2019)

Based on what was described above in terms of the dimensions proposed for the IPSS framework, the TFA project proceeded with its subdivision into relevant areas within each dimension, having focused on the literature (Bagnoli and Megali, 2011; Sanford, 2011; Arena, Azzone, and Bengo, 2015; Crucke and Decramer, 2016; Tomé, Meira, and Bandeira, 2016; Gibbons and Jacob, 2018) and on the results obtained in the previous fieldwork, where information was collected regarding the daily reality and the specific needs of these institutions. This construction resulted in the following framework structure (Figure 2).

Figure 2 - Dimensions and sub-dimensions of the framework 


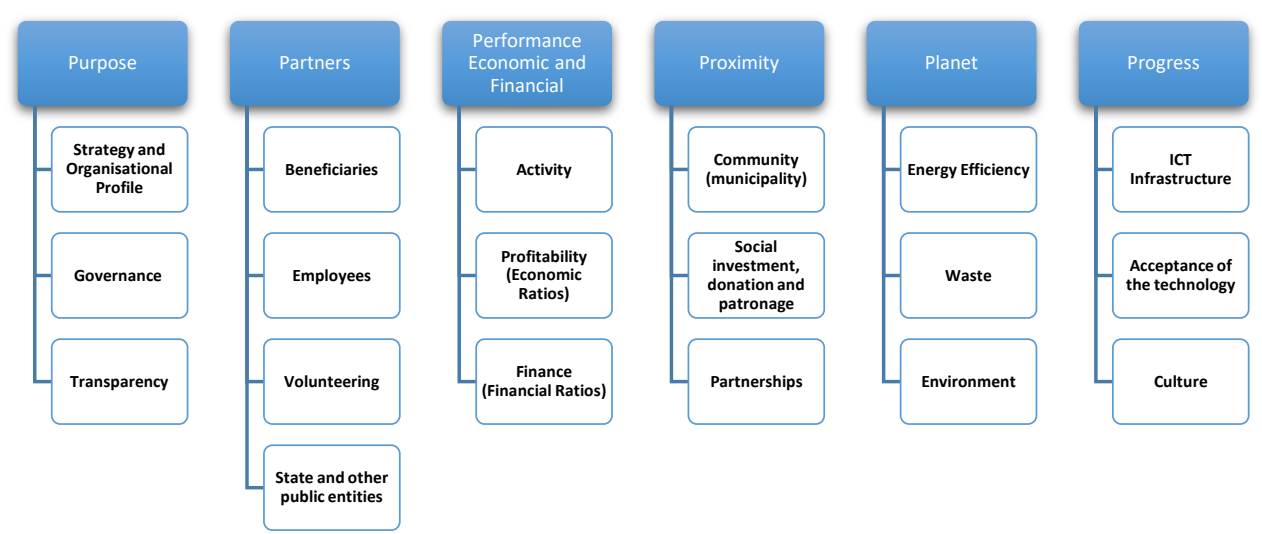

For each dimension/sub-dimension, the indicators considered capable of expressing the relevant information were defined, improving the accountability of the IPSS, whose construction was based on the literature review and on the current practices of these institutions, collected during the fieldwork. In general, 76 indicators were developed, divided by dimension and subdimension, as shown in Table 1 (in the annex you can see a greater detail of the framework, namely, the detailed description of each indicator and the corresponding objective, not forgetting the bibliographical base that underlies it).

Table 1 - Dimensions, subdimensions and indicators of the proposed framework

\begin{tabular}{|c|c|c|c|}
\hline \multirow{2}{*}{ Dimension } & \multirow{2}{*}{ Sub-dimension } & \multicolumn{2}{|c|}{ Number of Indicators } \\
\hline & & Sub-dimension & Dimension \\
\hline \multirow{3}{*}{ Purpose } & Strategy and organisational profile & 7 & \multirow{3}{*}{11} \\
\hline & Governance & 3 & \\
\hline & Transparency & 1 & \\
\hline \multirow{4}{*}{ Partners } & Beneficiaries & 3 & \multirow{4}{*}{16} \\
\hline & Employees & 8 & \\
\hline & Volunteering & 4 & \\
\hline & State and other public entities & 1 & \\
\hline \multirow{3}{*}{ Performance } & Activity & 8 & \multirow{3}{*}{16} \\
\hline & Profitability (Economic Ratios) & 3 & \\
\hline & Finance (Financial Ratios) & 5 & \\
\hline \multirow{3}{*}{ Proximity } & Comunity (municipality) & 5 & \multirow{3}{*}{16} \\
\hline & Social investment, donation and patronage & 4 & \\
\hline & Partnerships & 7 & \\
\hline \multirow{3}{*}{ Planet } & Energy Efficiency & 2 & \multirow{3}{*}{6} \\
\hline & Waste & 3 & \\
\hline & Environment & 1 & \\
\hline \multirow{2}{*}{ Progress } & ICT infrastructure & 3 & \multirow{2}{*}{11} \\
\hline & Acceptance of the technology & 6 & \\
\hline
\end{tabular}


It should be noted that, in addition to the 76 primary indicators, agglomerated (average) indicators are also proposed which will provide stakeholders with a broader vision of the generality of these institutions, but which may also help establish a benchmarking process for them.

\section{Presentation and discussion of results}

To validate and evaluate the analysis framework, a pilot test was carried out which included 7 IPSS, with data referring to the years 2018, 2019 and 2020. The main objective of this test is to calculate the framework's indicators in its different dimensions and sub dimensions. This pilot test aimed to identify the main trends, in an analysis by different dimensions, and to analyse the adequacy of the first results in relation to the expectations formulated based on the literature review. The results obtained in the pilot test and its discussion are presented below, in an analysis by each of the six dimensions of the framework.

\section{Dimension Purpose}

Graph 1 shows the results for the Purpose dimension indicators, taking into account their subdimensions (except for the transparency sub-dimension, which, as explained above, is not collected through the questionnaire).

Graph 1 - Results for Purpose dimension indicators

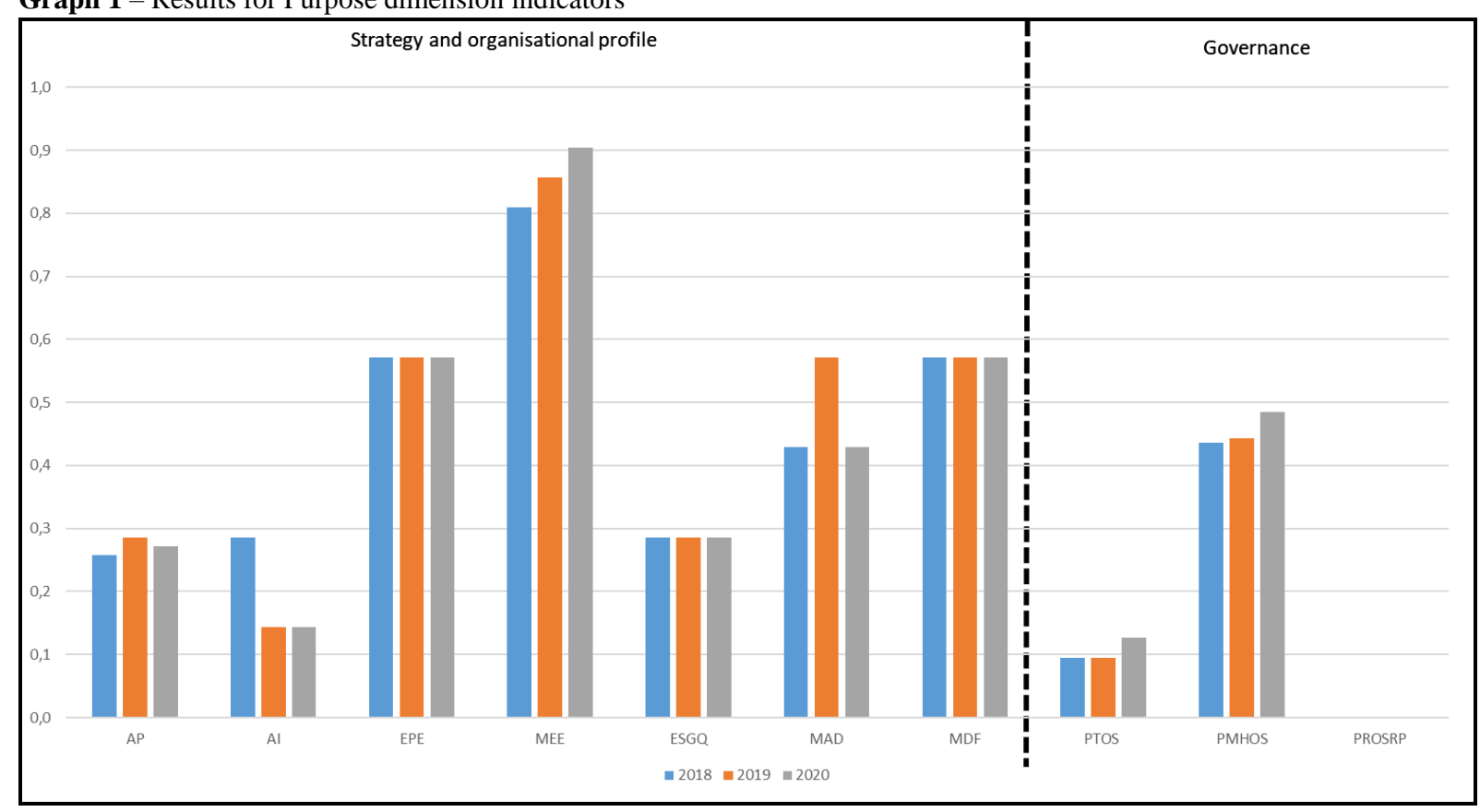

The analysis of Graph 1, with regard to the strategy and organizational profile sub-dimension, 
shows that the AP indicator (Main Activities) remains substantially constant during the 3 years under analysis. Through this indicator, it can be seen that the pilot test entities carry out, primarily, approximately $27 \%$ of the main activities that, in view of the legislation in force, they can carry out. These results are indicative that the IPSS of the pilot sample seek to specialise and avoid diversification. The AI indicator (Instrumental Activities) has a low value, decreasing from 2018 to 2019 and maintaining the same value in 2020, indicating that, in that year, only about $15 \%$ of the IPSS carry out other activities besides the main one. The joint analysis of these indicators seems to support what was just mentioned and is related to the search for specialisation in the activities carried out. However, the fact that a very small percentage of IPSS carry out other activities besides their main one may also indicate a lack of initiative to pursue activities that allow them to be more financially sustainable.

The EPE indicator (Existence of Strategic Plan) remains constant in the period under review and informs that approximately $57 \%$ of the IPSS in the pilot test have defined a strategic plan. An identical percentage is obtained for the MDF (Function Description Manual) and MAD (Performance Assessment Models) indicators, although the latter only for the year 2019. The ESGQ indicator (Existence of a Quality Management System) is approximately 28\%, meaning that only $28 \%$ of IPSS have a quality management system. The MEE (Entity's Strategic Maturity) indicator is the one with the highest values and has evolved positively over time, standing at 0.9 in 2020 . This indicator allows us to conclude that, in that year, $90 \%$ of the IPSS have defined their mission, vision and strategic objectives.

In the Governance sub-dimension, the PTOS indicator (Participation of Non-Member Employees in Governing Bodies) shows a slight increase in 2020 compared to 2019, but still indicates that, on average, corporate bodies only include about $10 \%$ of non-member employees. As for the PMHOS indicator (Parity between Women and Men in Governing Bodies) it showed a very slight increase in the period under analysis and, in 2020 , its value is very close to $50 \%$, which reflects that in the IPSS of the pilot test there is parity between men and women. The PROSRP indicator (Weight of Remuneration of Corporate Bodies in Personnel Remuneration) is zero in all periods under analysis, meaning that in the IPSS of the pilot sample, members of the management bodies are not remunerated.

From the results just presented, it is highlighted that it is still necessary for the IPSS to improve the strategy and the organisational profile, namely through the introduction of management mechanisms such as the strategic plan, the quality management system, the job description 
manual and the performance evaluation models, which will allow for greater professionalization of management. The results also show that the IPSS still have to act strongly in the improvement of Governance, either through the participation of employees in the management bodies, or through the professionalization of these same management bodies. The evolution of indicators in this dimension does not seem to have been affected by the pandemic caused by COVD-19.

\section{Partners Dimension}

Graph 2 shows the results for the indicators of the Partners dimension and taking into account their sub-dimensions beneficiaries, employees, volunteering, suppliers and State.

Graph 2 - Results for the Partners dimension indicators

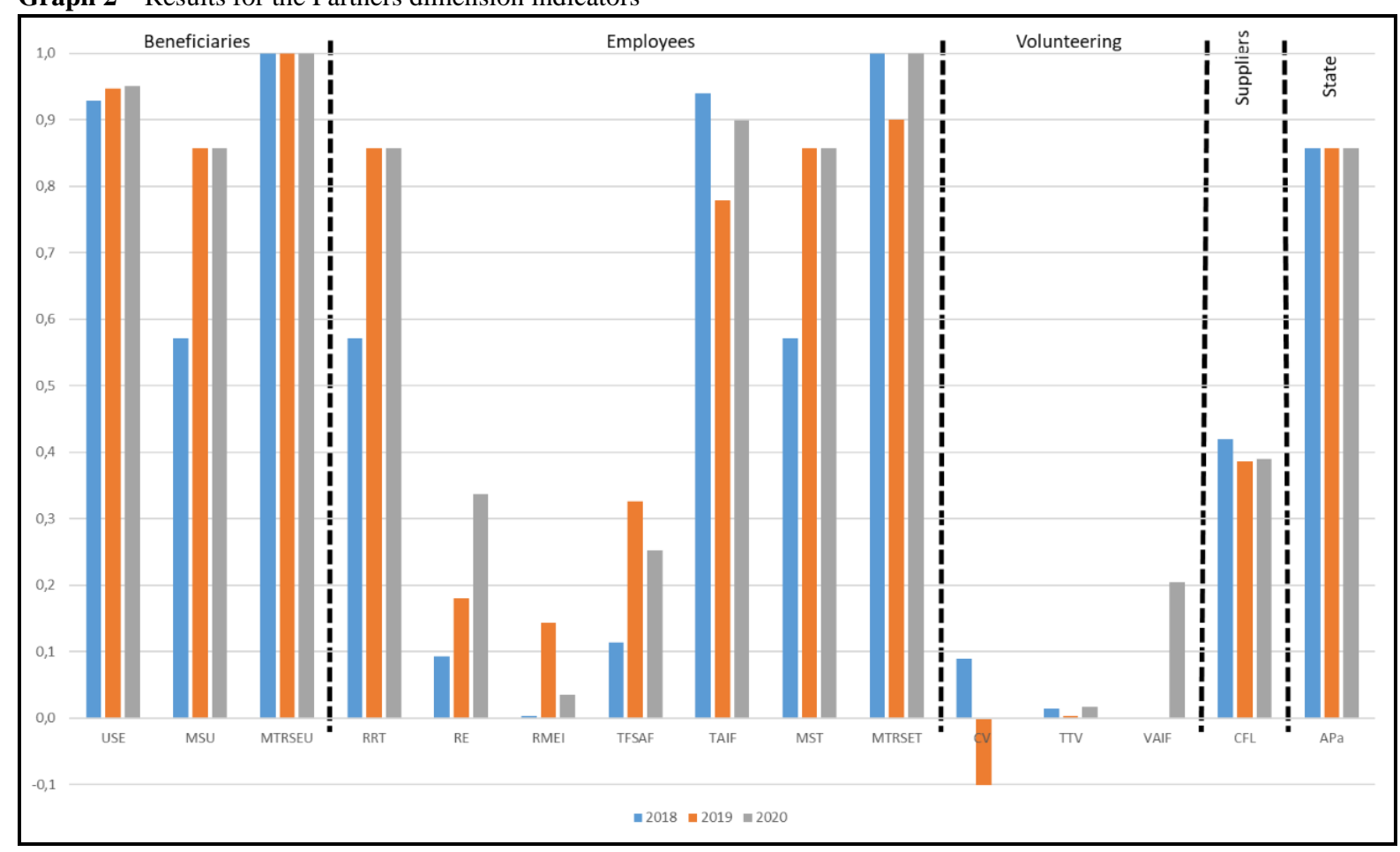

As can be seen in Graph 2, in the beneficiary sub-dimension, the USE indicator (Users Served by the Entity) shows a slight increase from 2018 to 2020 . This year, the value of the indicator indicates that the IPSS of the pilot sample serves about 95\% population, demonstrating that these IPSS serve a number of users very close to demand. The MSU indicator (monitoring user satisfaction) also shows a growth from 2018 to 2019, remaining the same in 2020. In these last two years, around $85 \%$ of the IPSS in the pilot sample assess user satisfaction. The MTRSEU indicator (monitoring the handling of complaints/suggestions/compliments from users) has a 
value of $100 \%$ in three years, which informs us that the IPSS, which assesses user satisfaction, dealt with $100 \%$ of complaints/suggestions/compliments received from users.

Regarding the employees sub-dimension, the RRT indicator (Holding Meetings with Employees) and the MST indicator (Monitoring Employees' Satisfaction) show the same values and the same growth trend from 2018 to 2019, both maintaining the value of 2019 in 2020 . In these years, the aforementioned indicators show that approximately $85 \%$ of the IPSS hold meetings with employees and have a system to monitor their satisfaction. The MTRSET indicator (Monitoring the Handling of Complaints/Suggestions/Compliments of Employees) indicates that in 2018 and 2020, the IPSS of the pilot test dealt with all the complaints/suggestions/compliments of employees. In 2019, the value is a little lower, standing at around 90\%. The TAIF indicator (Employees who benefit from Information and Vocational Training Actions during year $\mathrm{N}$ compared to the total number of employees) fluctuates in the period under analysis and stands at approximately $90 \%$ in 2020 , meaning that this is the percentage of employees which benefited from information and training actions during the year in question.

Also in the employees sub-dimension, the RE indicator (Job Turnover) shows a growth trend, although this is more accentuated from 2019 to 2020, indicating that this year employment turnover is roughly 33\%. This sharper increase in job turnover in 2020 may be related to the pandemic situation due to COVID-19, however, given the low turnover, the employment provided by the IPSS of the pilot test can be considered lasting. With regard to the RMEI (Recourse to Inclusive Employment Measures) indicator, analysing its values, it appears that the IPSS made very weak use of inclusive employment measures. In 2020, only around $3 \%$ of employees were recruited in this way. Finally, the TFSAF indicator (Employees with Higher Education who work in their Training Area compared to the total number of workers) shows a growth from 2018 to 2019 and a decrease from 2019 to 2020, but this year, about $25 \%$ of employees with training superior worked in their area of training.

In the sub-dimension, volunteering, all indicators have very low values, and without expression, the CV (Volunteer Capture) indicator in 2019 is negative, which indicates that the role of volunteers in the entities belonging to the pilot test is still not very significant. This may be due to the requirement of minimum professionals to obtain State subsidies, combined with the need for integration and training of volunteers, which requires time and resources and the need for volunteers to work in the IPSS through a duly established commitment, allowing the IPSS 
schedule their activities and make sure they have that level of volunteers. In the field work, some institutions stated that "It is more complicated to train volunteers than the benefits they bring, because they tend to be just passing through".

In the Suppliers sub-dimension, the CFL indicator (Purchases from Local Suppliers) slightly decreases from 2018 to 2019, having remained in 2020. This year, around 39\% of purchases are made from local suppliers.

In the State sub-dimension, the APa indicator (Partnership Agreements) remains practically constant and close to $85 \%$, indicating the percentage of IPSS in the pilot test that have partnership agreements with public sector institutions.

The analysis of the sub-dimensions of users, employees, volunteers, suppliers and the State, shows that the performance level of the indicators by sub-dimension is irregular, with the voluntary sub-dimension showing the worst results. This fact does not seem very strange given the difficulty that entities face in having volunteers available to regularly carry out the activities. With regard to the sub-dimension of employees, it is important to emphasize the need to adjust the functions performed to the training of employees, making the best use of their skills, as well as devoting more attention to monitoring and treating the employees' opinions.

\section{Dimension Performance}

Graph 3 presents the results for the indicators of the Performance dimension, taking into account their activity, profitability and finance subdimensions and, in Table 1, the results for the VAB (Gross Added Value) indicators of the profitability subdimension, LG (General Liquidity), SOL (Solvency) and FM (Working Capital) of the finance sub-dimension.

Graph 3 - Results for the Performance dimension indicators 


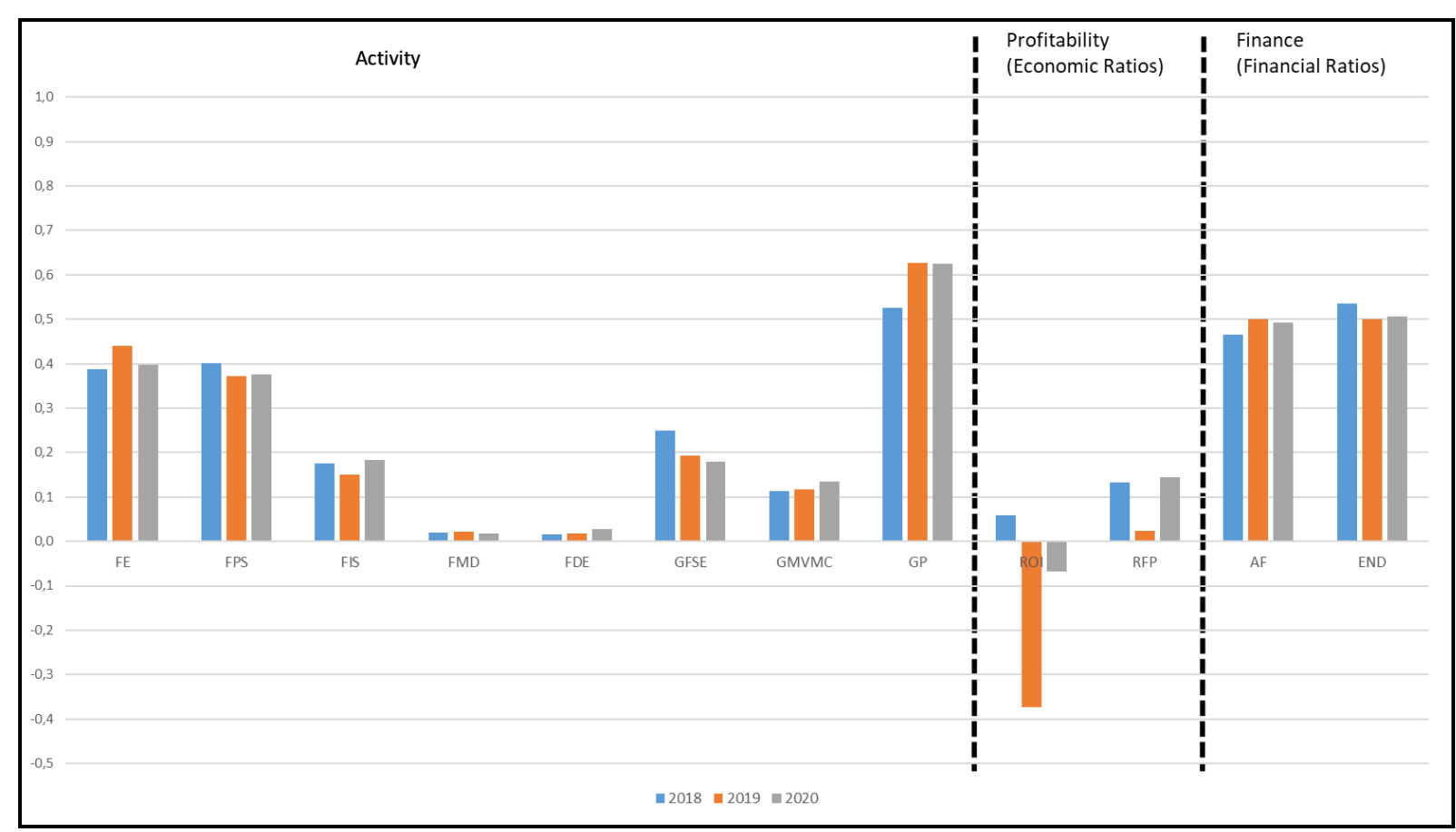

The analysis of Graph 3, for the activity sub-dimension, and with regard to the FE financing indicators (State Financing compared to total financing), FPS (Service Provision Financing compared to total financing), FIS (Social Investment Financing compared to total funding), FMD (Funding of Patronage and Donations compared to total funding) and FDE (Financing of Donations in Kind compared to total funding), it appears that the fluctuations in temporal terms are very small and that the State funding (represents between 38 and 44\%) in addition to the financing from the provision of services (amount paid by the user, represents between 38 and $40 \%$ ) are the ones that have greater expression, representing, together, approximately $80 \%$ of the financing of the IPSS of the pilot sample. Funding from social investors also has some expression (approximately $18 \%$ in 2020, the year with the highest value) but what comes from donors (including in-kind donations) is very small, at approximately 4\%. Although our results refer to a very small set of IPSS, when compared with those obtained in a study published by the CNIS (2018) these ratios were situated, respectively, at approximately 39\% (State financing), 32\% (Provision of Services), 7\% (Social Investment) and 4\% (Donations, including in Kind) which reveals that, with the exception of funding through patronage, there was some growth in funding through the different channels.

Still in terms of the activity sub-dimension, but now in an analysis of the cost structure, it appears that personnel costs are clearly the ones that have a greater weight in operating costs (GP indicator), representing about $62 \%$ of operating costs in the years 2019 and 2020. This is followed by expenses with external supplies and services that represent approximately $18 \%$ of operating expenses (GFSE indicator) in the same years and, finally, expenses with goods sold 
and materials consumed, which represent, in the same period, around $12 \%$ of operating expenses (indicator GMVMC). In the CNIS study (2018) personnel expenses represented 58\% of total expenses, expenses with external supplies and services representing approximately $20 \%$ of total expenses and expenses with goods sold and materials consumed representing approximately $10 \%$ of total expenses. The comparison with our study cannot be directly analysed as our study analyses the structure of expenses in relation to operating expenses and the CNIS study (2018) uses total expenses. However, it is clear that the distribution follows roughly the same proportion.

The analysis carried out indicates that the IPSS should invest more in attracting funders, namely, in terms of social investment and donors, and the path of transparency and accountability should be an option. It also demonstrates that the expenditure structure, assuming the character of IPSS service providers, is adequate since they are heavily dependent on labour. Regarding the profitability sub-dimension, it appears that the ROI (Return on Investment (social investment, State, patronage and donations)) is strongly negative in 2019, slightly improving in 2020, but remaining negative, while the return on equity (RFP indicator), although very low, is positive. The year with the worst performance is 2019. In the CNIS study (2018) the return on equity is approximately $1 \%$, which is lower than what we obtained. With regard to the VAB (gross added value) (see Table 1), its value grows in the period under analysis. In global terms, although the ROI is very low and even negative in 2019 and 2020, the VAL makes an interesting contribution from the IPSS to the community in which they operate and to the economy in general.

In the finance sub-dimension, it can be seen that the indicator AF (Financial Autonomy) rises slightly during the period under analysis and stands at approximately $49 \%$ in 2020 . The END (Indebtedness) indicator has the opposite behaviour and, in 2020, stands at approximately 50\%. To complete the analysis, and observing Table 1, it appears that both the LG indicator (general liquidity) and the SOL indicator (solvency) have very high values and do not undergo a significant variation over the period under analysis. The FM (working capital) indicator has values that, given the general liquidity, can be considered excessive. Considering these results, it is understood that the financial management of entities needs some attention, indicating that the IPSS in the pilot sample could, with a more adequate financial management, take advantage of excess short-term funding, improving their financial function.

Tabela 1 - Results for the VAB, LG, SOL and FM indicators 


\begin{tabular}{lrrrr}
\hline \multirow{2}{*}{ Indicator } & \multicolumn{3}{c}{ Year } \\
\cline { 2 - 5 } & \multicolumn{2018}{c}{$\mathbf{2 0 1 9}$} & $\mathbf{2 0 2 0}$ \\
\hline VAB & 291454 & 312892 & 344619 \\
LG & 2,92 & & 2,55 & 2,98 \\
SOL & 1,72 & & 2,16 & 1,80 \\
FM & 71393 & 68659 & 99078 \\
\hline
\end{tabular}

When compared to the CNIS study (2018), we found that financial autonomy (approximately $72 \%$ ), solvency (approximately 2.78) and general liquidity (approximately 5.38) are greater than those obtained in this pilot test.

\section{Dimension Proximity}

Graph 4 shows the results for the indicators of the Proximity dimension in its community, social investment and partnerships sub-dimensions. Table 2 presents the results for the indicators of the social investment, donors and patronage sub-dimension.

Graph 4 - Results for the indicators of the Proximity dimension in its community, social investment and partnerships sub-dimensions

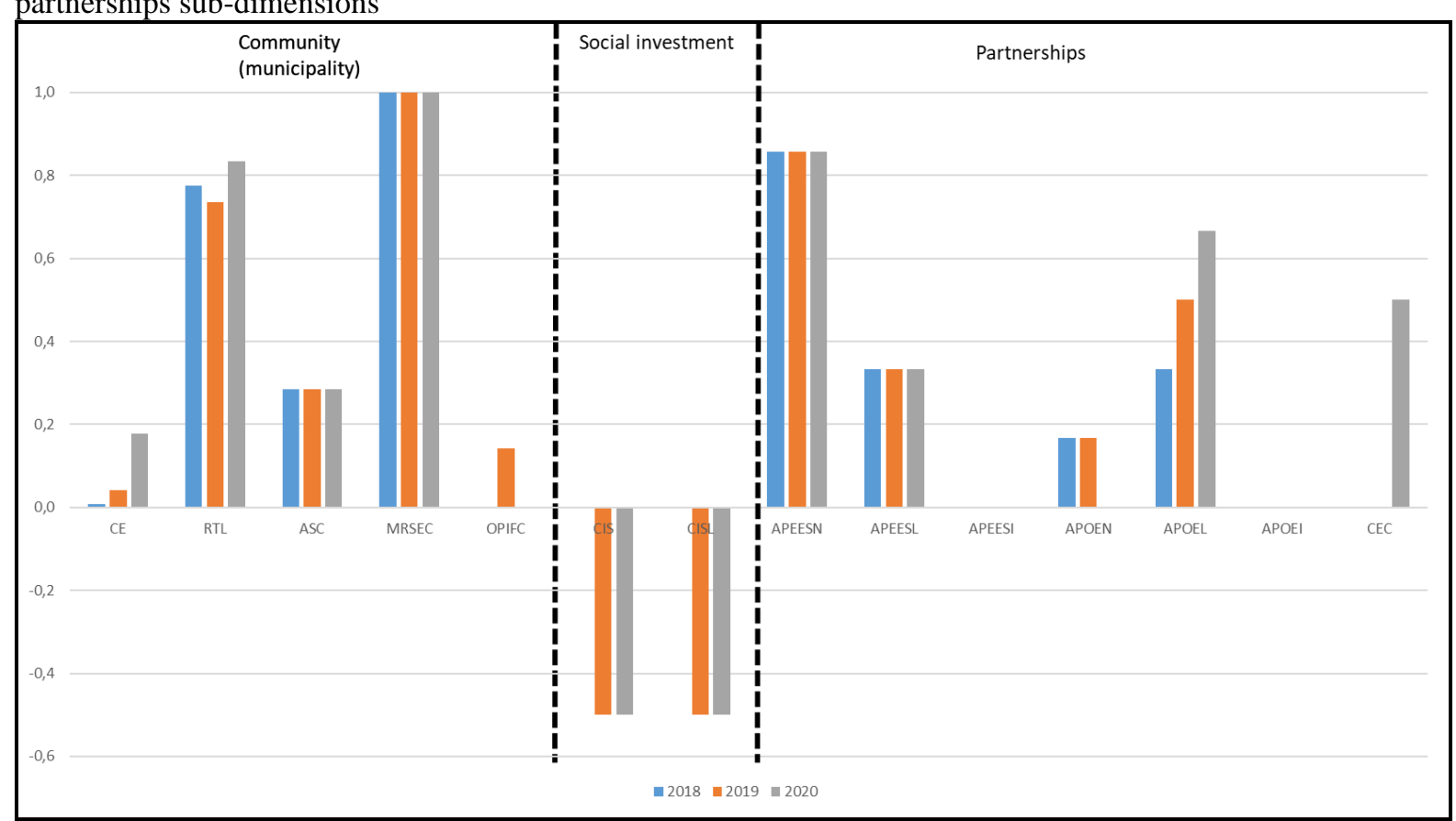

As can be seen in Graph 4, in the community sub-dimension, the EC indicator (Job Creation) remained low, showing an increase in 2020, but even so the percentage of job creation in 2020 is below $20 \%$. These values may mean that the IPSS in the sample are in a phase of stability compared to the personnel structure recommended by the State bodies or that they are unable 
to increase their staff due to financial constraints. The increase in 2020 may result from the necessary responses to the COVID-19 pandemic. The RTL (Representation of Local Employees) indicator presents a small variation in the period under analysis and, in 2020, it is around $83 \%$. This indicator is relevant, showing that the IPSS in the pilot sample essentially attract local employees. The entity's concern with community satisfaction is still at low levels, since less than $30 \%$ of the IPSS in the sample indicate that they assess community satisfaction, as can be seen from the ASC indicator (Community Satisfaction Assessment). Nevertheless, the MRSEC indicator (Monitoring the Handling of Complaints/suggestions/compliments from the Community) indicates that the IPSS that assesses satisfaction and monitors the complaints/suggestions/compliments of the community have handled, throughout the period under review, all complaints/suggestions/compliments from the community they received. The interaction of the IPSS with the community through the provision of information and training programs to the community, OPIFC indicator, is also of little significance, since it only presents a value in the year 2019 and only about $15 \%$ of the IPSS in the sample indicated that they had provided this offering to the community.

With regard to subdimension partnership the APEESN indicators (Partnership Agreements with Entities of Social Economy National Counterparts) and APEESL (Partnership Agreements with Entities of Social Economy Local) remain constant during the period under review and are located respectively in $86 \%$ and $33 \%$. There are no partnership agreements with international social economy entities, APEESI indicator, and partnerships with other social economy entities, APOEN indicator is low in 2018 and 2019 and, in 2020, it is zero. The APOEL indicator (Partnership Agreements with Local Social Economy Entities) shows an increase in the period under analysis, reaching its value in 2020 at approximately $67 \%$, revealing a strong connection to the community in which the IPSS are located. The CEC (Curricular Internships) indicator only shows a value in 2020 and is 50\%, revealing that the IPSS is managing to attract young people for social economy activity.

With regard to the social investment sub-dimension, the CIS (Attracting Social Investors) and CISL (Attracting Local Social Investors) indicators are negative in 2019 and 2020, indicating that the number of social investors decreased compared to 2018. In the same dimension, and as can be seen in table 2, the indicators CMD (Capture of Sponsors and/or Donors) and CISL (Capture Local Social Investors) rises a lot in 2019, decreasing in 2020 to the levels of 2018. These indicators are variations, the rise in 2019 may be due to COVID-19, which mobilised solidarity and, possibly, the increase in donors also to the IPSS. 
Tabela 2 - Results for the Social Investment, Donors and Patronage sub-dimension indicators

\begin{tabular}{|c|c|c|c|}
\hline \multirow{2}{*}{ Indicator } & \multicolumn{3}{|c|}{ Year } \\
\hline & 2018 & 2019 & 2020 \\
\hline CMD & 0,2 & 50,5 & 0,5 \\
\hline CMDL & 0,1 & 50,5 & 0,3 \\
\hline
\end{tabular}

From the analysis of this dimension, it can be seen that the contribution of the IPSS to the community is significant, contributing to the dynamisation of the community in which they operate, namely in terms of employment and partnerships.

\section{Dimension Planet}

In an analysis of Graph 5, where the results for the indicators of the Planet dimension are presented, considering their Energy Efficiency (MEEe and MECA), Waste (RSR, RR and MR) and Environment (CA) subdimensions, we can assess the Planet dimension. It appears that the waste and environment indicators show the strong concern of the IPSS with environmental aspects. In a more detailed analysis, it can be observed that the RSR (Selective Waste Collection), RR (Waste Reuse) and MR (Waste Mitigation) indicators, although fluctuating during the period under analysis, present higher values, in most cases. $85 \%$, which shows that the entities in the pilot sample use measures to treat or reuse waste. The CA (Environmental Awareness) indicator also presents values above 50\%, in line with what has just been exposed.

Graph 5 - Results for the Planet dimension indicators

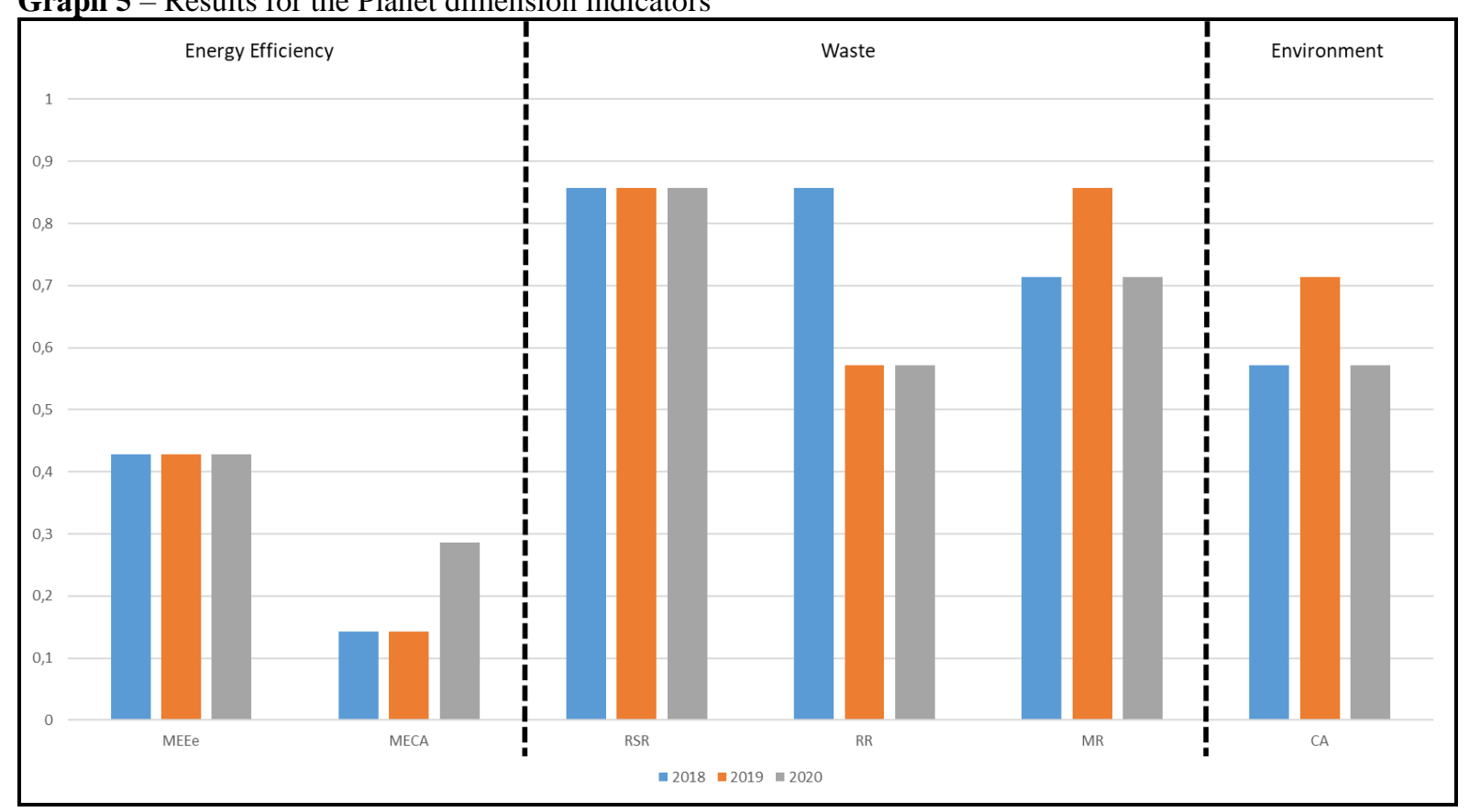

The greatest weakness found in this dimension is the Energy Efficiency sub-dimension, in which the indicators are still low, meaning, in the case of the MEEE (Energy Efficiency 
Measures) that only approximately $43 \%$ of the IPSS in the pilot sample carried out the implementation of energy efficiency measures. In the case of the MECA (Water Consumption Efficiency Measures) indicator, the percentage of IPSS that implemented water consumption efficiency measures is lower, although it rose significantly in 2020, standing at approximately $29 \%$.

From a time perspective, it should be noted that most indicators stagnated between 2019 and 2020 and 2 indicators (MR and CA) showed a slight decrease in that period. These results are in line with the study by Liu, Bunditsakulchai and Zhuo (2021), which showed a substantial change in the pattern of waste generated during the pandemic. Thus, in the case of the entities analysed, this drop can be justified by the occurrence of the COVID-19 pandemic, which relegated environmental aspects to the background in light of health concerns.

In global terms, it is understood that, from the analysis of the results for this dimension, the IPSS are aware of the need to preserve the environment. However, there is still room for improvement, especially in the energy efficiency sub-dimension, which needs more attention. Occasionally, the fact that less than $50 \%$ of the entities in the pilot sample do not have efficiency measures is related to issues of a financial nature.

\section{Dimensão Progress}

Graph 6 shows the results of the indicators of the Progress dimension over the study period, considering the sub-dimensions ICT infrastruture, acceptance of the techonology and culture.

From its analysis and with regard to the ICT infrastruture sub-dimension, a great disparity in behaviours can be verified regarding the adoption of new technologies, with insignificant values being found for the VPN (Virtual Private Network) indicator, which indicates that only about $14 \%$ of the IPSS in the pilot test gives access via virtual private network. The percentage of IPSS that owns LAN (Local Area Network), although it decreased in 2019 and maintained in 2020, is, for those years, $43 \%$. As for the LI (Connection to the Internet) indicator, it appears that all IPSS have this connection in the three years.

Graph 6 - Results for the Progress dimension indicators 


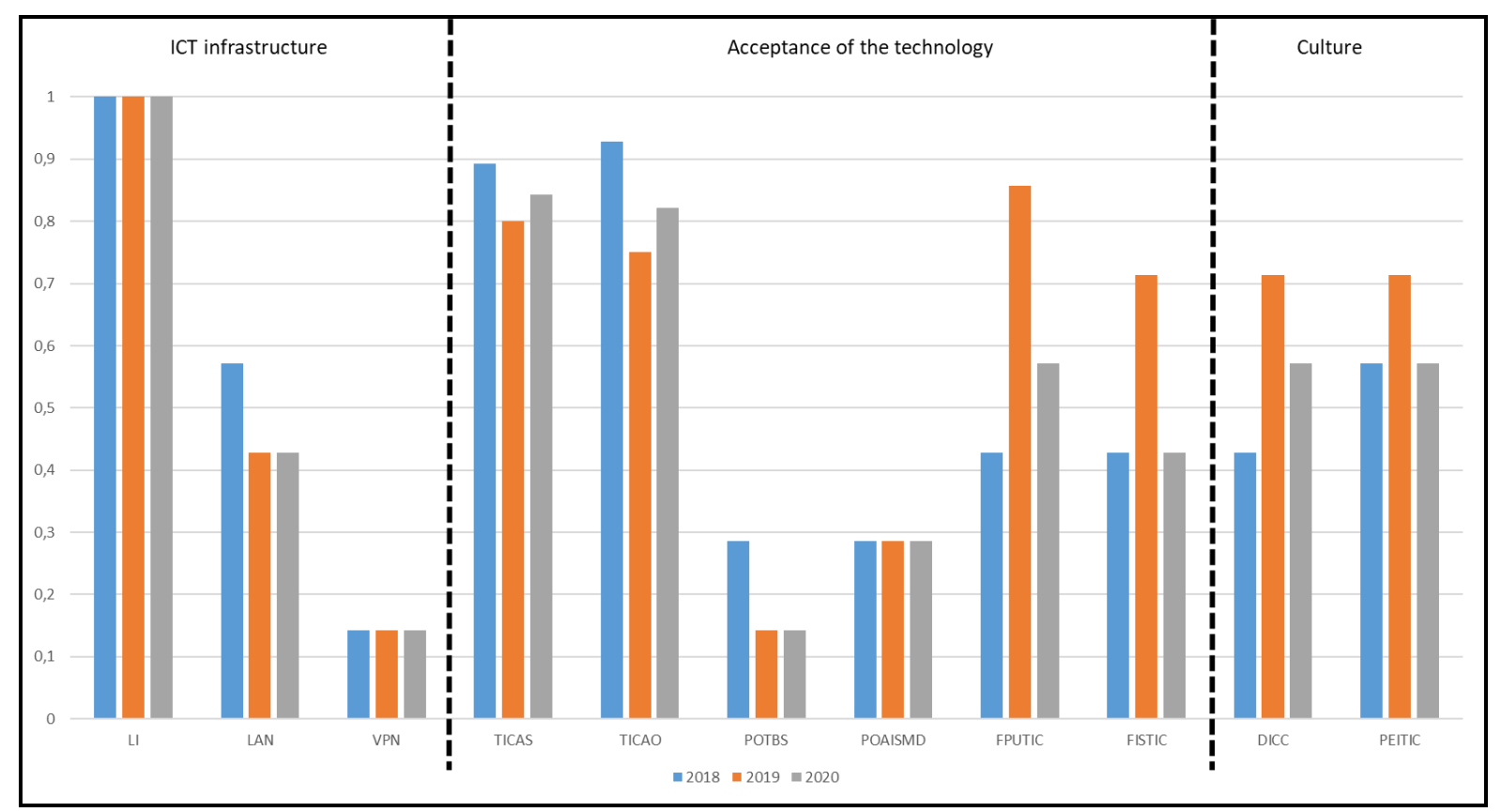

When the results of the acceptance of the technology subdimension are observed, it is verified through the indicators TICAS (ICT in Support Activities) and TICAO (ICT in Operational Activities) that the IPSS of the pilot test already use ICT in the development of their activities, although, from a time point of view, these indicators have decreased slightly compared to 2018 . In line with these results are also the results for the FPUTIC indicators (Facilitator in the Promotion of the Use of ICT) and FISTIC (Facilitator of Interaction with Stakeholders through ICT) in which the IPSS are assumed as facilitators of ICT and these indicators had the highest value in 2019, respectively 86 and $71 \%$. The decrease in this indicator could mean that there was not the expected adhesion by the stakeholders, or even that the IPSS were unable to maintain the same position. In this sub-dimension, the indicators POTBS (Online Platform for Trading Goods and/or Services) and POAISMD (Online Platform for Attracting Social Investors) reveal that the IPSS in the pilot test still uses these platforms very little.

Finally, in the culture sub-dimension, the indicators DICC (Dissemination of the Cultural Identity of the Community) and PPEITIC (Promotion of Intergenerational Experiences through ICT) reveal an interesting level of involvement and show that the IPSS in the pilot sample promote the dissemination of experiences through of ICTs, with 2019 being the year in which the highest percentage of IPSS do so (about 71\%). From our point of view, the fact that there is a decline in 2020 may be related to the pandemic, which may be due to the lack of conditions to carry out activities in this forum, given the great demands placed on this type of entity. 
In summary, there are no major disparities in the indicators by sub-dimensions, but the most accepted sub-dimension is Culture, which uses technology to promote the organisation's cultural identity in the community. In a time perspective, the general trend is for improvement until 2019, but there is a significant setback in the year 2020, with most indicators regressing or stagnating, which suggests that this dimension, although it turns out to be a concern of the IPSS, they were unable to maintain the effort made in 2019. Given the pandemic context, an increase in the use of new technologies would be expected. The fact that this did not happen may reflect the specificity of the sector under analysis, which privileges other dimensions.

\section{FINAL CONSIDERATIONS}

Based on the literature review carried out, we may verify a diversity of approaches to accountability, which impact the various dimensions of the activity of organisations in general and of the IPSS in particular. In this sense, and based on an extensive literature review, a framework was proposed that seeks to contemplate these different dimensions of accountability and which ranges from the concern with the correct definition of the main object of an IPSS (Mission, Vision, Values), evident through the entity's strategy and organisational profile, to its capacity to incorporate new technologies in favour of adapting to the demands arising from the digital era.

It should be noted that in the accountability assessment process, the relationship that the IPSS maintains with stakeholders, both internally and externally, is extremely relevant, fostering strong and close relationships for the benefit of the community and the sustainable development of the entity itself. Also worthy of reference is the disclosure of its operation and performance, with reports of a social, economic and financial and even environmental nature. The IPSS practice in all these dimensions should be assessed and disclosed, as they are intrinsic factors of the institution and relevant to the improvement of its accountability.

In order to assess the framework's ability to provide information that allows the IPSS to assess their accountability individually and compared with the other IPSS, a pilot test was carried out with 7 IPSS and data for the years 2018, 2019 and 2020. From the analysis of the results, it was possible to make a diagnosis of these IPSS in the various dimensions and subdimensions of the framework, with the exception of the transparency subdimension. It was also possible to identify trends in the indicators that allow us to know the weaknesses and where greater intervention and effort is needed. 
In terms of the Purpose dimension, the need for the IPSS to improve the strategy and organisational profile was identified, through the introduction of management mechanisms that allow for greater professionalization of management, as well as the need to improve Governance or through the participation of workers in the management bodies or through the professionalization of these same management bodies.

With regard to the Partners dimension, the low values of the indicators of the voluntary subdimension are highlighted, demonstrating the low attractiveness of these entities for attracting volunteers. It was also possible to identify the need to adjust the functions performed by workers to their respective training, as well as devoting more attention to monitoring and treating the workers' opinions.

With regard to the Performance dimension, the low representation of funding via donors and social investors stands out, alerting to the need for these entities to invest in attracting this type of funding. It was also possible to identify an excess of short-term financing that needs an improvement in the financial function of these entities.

Regarding the Proximity dimension, it was possible to identify a significant contribution of the IPSS to the community in which they operate, namely through employment and partnerships.

In terms of the Planet dimension, it was possible to identify the concern of the entities involved in the pilot test with respect to the preservation of the environment, but that still does not take place in terms of energy efficiency measures, possibly due to the financial restrictions to which they are subject.

Finally, with regard to the Progress dimension, it was possible, in general terms, to identify an improvement from 2018 to 2019, but which stagnated or regressed in 2020. Therefore, in this field there is a significant way to go.

Considering that the years under analysis include the beginning of the pandemic, some of the variations identified can be explained by this condition. In this context, variations were identified in the Partners dimension in terms of worker turnover, which could represent a possible negative effect of COVID-19. This result crosses with the job creation indicator, in the Proximity dimension, which may have increased in 2020 due to the necessary responses to the pandemic. It is also possible that the setback of indicators related to the Progress dimension is linked to the COVID-19 effect, which forced these entities to focus on other aspects that became more urgent during the pandemic period. 
On the other hand, the Performance dimension does not seem to have suffered significant effects from COVID-19, possibly because support was granted by the State that allowed, in this period, to alleviate the difficulties felt in the context of a pandemic. Also, in the evolution of the Purpose and Planet dimension indicators, it does not seem to have been affected by the pandemic caused by COVID-19.

The framework designed can enable, beyond the diagnosis based on the results obtained from the indicators, the modernisation of the social economy sector. This is because, after the diagnosis phase, it is possible for each institution to introduce the necessary improvements to make accountability feasible, which is imperatively required (hard and soft law), with the ultimate goal of fulfilling its mission and individual and collective sustainability.

We believe that the framework designed answers the research question: How to promote accountability (social, financial and economic) in the social economy sector, in particular: the case of the IPSS?, however, as this is an exploratory article, it incorporates the limitation that this is a pilot test with only 7 entities. In this sense, future work proposes the collection of data from a bigger number of entities to calculate the indicators with the objective of assessing whether the framework fulfils its objective - the assessment of the accountability of entities in the social economy sector, particularly the IPSS. Also it will interesting to question the entities to know if individually the framework fulfils their needs for evaluate their accountability.

\section{Acknowledgments}

The European Regional Development Fund (FEDER), through Operational Competitiveness and Internationalisation Program (COMPETE 2020 - POCI), and the Foundation for Science and Technology (FCT) financed this research, with reference number POCI-01-0145-FEDER030074.

\section{Bibliography}

Aimers, J. and Walker, P. 2008a. "Alternative models of accountability for third sector organisations in New Zealand". University of Otago. New Zeland.

Aimers, J. and Walker, P. 2008b. "Is community accountability being overlooked as a result of government-third sector partnering in New Zealand?" Aotearoa New Zealand Social Work, 3, 14-24.

Akingbola, K. (2006). Strategy and HRM in nonprofit organizations: Evidence from Canada. The International Journal of Human Resource Management, 17(10), 1707-1725.

Akingbola, K., \& van den Berg, H. A. (2019). Antecedents, consequences, and context of employee engagement in nonprofit organizations. Review of Public Personnel Administration, 39(1), 46-74.

Álvarez-González, L. I., García-Rodríguez, N., Rey-García, M., \& Sanzo-Perez, M. J. (2017). Businessnonprofit partnerships as a driver of internal marketing in nonprofit organizations. Consequences for nonprofit performance and moderators. BRQ Business Research Quarterly, 20(2), 112-123. 
Arena, M., Azzone, G. and Bengo, I. 2015. "Performance Measurement for Social Enterprises". Voluntas, 26(2), pp. 649-672. doi: 10.1007/s11266-013-9436-8.

Arshad, R., Bakar, N.A., Thani, N.Y.and Omar, N. 2013. "Board Composition and Accountability of Non-Profit Organizations". The Journal of Applied Business Research, 29 (4), 1021-1030.

Atan, R., Alam, M. and Said, J. 2017. "Practices of corporate integrity and accountability of non-profit organizations in Malaysia”. International Journal of Social Economics, 44 (12), 2271-2286.

Austin, M. J., Regan, K., Samples, M. W., Schwartz, S. L., \& Carnochan, S. (2011). Building managerial and organizational capacity in nonprofit human service organizations through a leadership development program. Administration in Social Work, 35(3), 258-281

Awio, G., Northcott, D. and Lawrence, S. 2011. "Social capital and accountability in grass-roots NGOsThe case of the Ugandan community-led HIV/AIDS initiative." Accounting, Auditing \&Accountability Journal, 24 (1), 63-92.

Azman, N.A., Arshad, R. and Bakar, N.A 2015. "Do funding resources affect the accountability disclosure of non-profit organizations?" Asian Journal of Accounting Perspectives, 8, 35-45.

Bagnoli, L. and Megali, C. 2011. "Measuring performance in social enterprises." Nonprofit and Voluntary Sector Quarterly , 40(1), p. 149-165. doi: 10.1177/0899764009351111.

Ban, C., Drahnak-Faller, A., \& Towers, M. (2003). Human Resource Challenges in Human Service and Community Development Organizations: Recruitment and Retention of Professional Staff. Review of Public Personnel Administration, 23(2), pp. 133-153. doi:10.1177/07.

Bakar, N.A., Arshad, R., Azman, N.A. and Omar, N. 2013. "Organisational Characteristics and Accountability in Protecting Risk Exposures in Non-Profit Organisations." Journal of Energy Technologies and Policy, 3 (11), 479-489.

Bakar, N.A., Arshad, R., Azman, N.A. and Omar, N. 2014. "Effective Governance Structure and Accountability in Managing Risks for Non-Profit Organizations." Proceedings of World Business and Economics Research Conference.24 -25 February 2014, Rendezvous Hotel, Auckland, New Zealand, ISBN:978-1-922069-45-0.

Barret, M. 2001. "A stakeholder approach to responsiveness and accountability in non-profit organisations.” Social Policy Journal of New Zealand, Dec.2001 (17), 36-51.

Becker, A. 2018. "An experimental study of voluntary non-profit accountability and effects on public trust, reputation, perceived quality, and donation behaviour." Non-profit and Voluntary Sector Quarterly, 47 (3) $562-582$.

Becker, K., Antuar, N., \& Everett, C. (2011). Implementing an employee performance management system in a nonprofit organization. Nonprofit management and leadership , 21(3), pp. 255-271.

Bhati, A., \& Manimala, M. J. (2011). Talent acquisition and retention in social enterprises. Journal of Security and Sustainability Issues, 1(1), pp. 37-51.

Bielefeld, W. (2000). Metropolitan Nonprofit Sectors: Findings from NCCS Data. Nonprofit and Voluntary Sector Quarterly, 29(2), pp. 297-314.

Bontis, N., Ciambotti, M., Palazzi, F., \& Sgro, F. (2018). Intellectual capital and financial performance in social cooperative enterprises. Journal of Intellectual Capital.

Bovens, Mark. 2006. "Analysing and Assessing Public Accountability." A Conceptual Framework. European Governance Papers (EUROGOV) No. C-06-01, http://www.connexnetwork.org/eurogov/pdf/egp-connex-C-06-01.pdf.

Brooks, A. C. (2003). Challenges and Opportunities Facing Nonprofit Organizations . Public Administration Review, 63(4), pp. 503-506. JSTOR, www.jstor.org/stable/977405.

Brown, W. A. (2007). Board development practices and competent board members: Implication for performance. Nonprofit Management \& Leadership, 17(3), pp. 301-317.

Brunt, C., Dolch, N. A., Freeman, T. M., Mirabella, R., \& Weber, P. C. (2020). Undergraduate Nonprofit Education: Between Institutionalization and Recruitment.

Carvalho, A., Melo, S., \& Ferreira, A. P. (2016). Training in Portuguese non-profit organizations: the quest towards professionalization. International Journal of Training and Development, 20(1), 7891.

Chang, W. W., Huang, C. M., \& Kuo, Y. C. (2015). Design of employee training in Taiwanese nonprofits. Nonprofit and Voluntary Sector Quarterly, 44(1), 25-46. 
Choudhury, E. and Ahmed, S. 2002. "The shifting meaning of Governance: Public Accountability of Third Sector organizations in an emergent global regime." Journal of Public Administration, 25 (4) $-561-588$.

CNIS (2018). Importância económica e social das IPSS em Portugal. ISBN 978-989-20-9045-0.

Cole, D. C., Mondloch, M. V., Hogg-Johnson, S., \& Early Claimant Cohort Prognostic Modelling Group. (2002). Listening to injured employees: how recovery expectations predict outcomes-a prospective study. Cmaj, 166(6), 749-754

Connolly, C. and Kelly, M. 2011. "Understanding accountability in social enterprise organisations: a framework." Social Enterprise Journal, 7 (3), 224-237.

Connolly, P., \& York, P. (2002). Evaluating capacity-building efforts for nonprofit organizations. Od Practitioner, 34(4), pp. 33-39.

Conroy, D. K. 2005. "Non-profit organisations and accountability: A comment on the Mulgan and Sinclair frameworks." Third Sector Review, 11(1), 103-116.

Corbin, J. J. (1999). A study of factors influencing the growth of nonprofits in social services. Nonprofit and Voluntary Sector Quarterly, 28(3), pp. 296-314.

Costa, E., Ramus, T. and Andreaus, M. 2011. "Accountability as a Managerial Tool in Non-Profit Organizations: Evidence from Italian CSVs." Voluntas, 22, 470-493.

Crucke, S. and Decramer, A. 2016. "The development of a measurement instrument for the organizational performance of social enterprises." Sustainability, 8(2), p. 161 doi: $10.3390 / \mathrm{su} 8020161$.

Curi, D. P. (2007). Orientação para o mercado: a relação entre a orientação para a tecnologia e o marketing relacional . Doctoral dissertation, Universidade de São Paulo.

Decree-Law no 172-A/2014, de 14 de novembro, Diário da República nº221 - 1st serie, Assembleia da República, Lisboa. (Statute of IPSS).

Edwards, M., Onyx, J., Maxwell, H., \& Darcy, S. (2012). Meso level social impact: Meaningful indicators of community contribution [online]. Cosmopolitan Civil Societies: An Interdisciplinary Journal, $\quad 43(3), \quad$ pp. 18-37. Availability: <https://search.informit.com.au/documentSummary;dn=976161175005775;res=IELHSS> ISSN: 1837-5391.

Elkington, J. 1994. "Towards the sustainable corporation: Win-win-win business strategies for sustainable development." California management review, 36(2), pp. 90-100.

Elkington, J. 1999. “Cannibals With Forks: Triple Bottom Line of 21st Century Business.” London: John Wiley \& Son Ltd.

Ferreira, A.D., Santos, C. \& Curi, D. 2019. In XVII Conferência Internacional de Contabilidade e Administração (CICA) - "A Contabilidade na Era digital - oportunidades e desafios." 7 e 8 de novembro de 2019. ISCAP, Porto, Portugal.

Fletcher, A., Guthrie, J., Steane, P., Roos, G., \& Pike, S. (2003). Mapping stakeholder perceptions for a third sector organization. Journal of intellectual capital, 4(4), pp. 505-527. https://doi.org/10.1108/14691930310504536.

Freeman, R. E., Martin, K., \& Parmar, B. (2007). Stakeholder capitalism. Journal of business ethics, 74(4), 303-314.

Geurts, S., Schaufeli, W., \& Jonge, J. D. (1998). Burnout and intention to leave among mental healthcare professionals: A social psychological approach. Journal of Social and Clinical Psychology, 17(3), pp. 341-362.

Gibbons, K. and Jacob, M. 2018. "Emerging Possibilities: Adapting Carol Sanford's Stakeholder PENTAD for the Nonprofit and Public Sectors." Proceedings of the 60th Annual Meeting of the ISSS-2016, January, 1(1), http://journals.isss.org/index.php/proceedings60th/article/view/2984/1028.

GRI 4. 2013. "Sustainability Reporting Guideline G4: Implementation Manual.” Global Reporting Initiative.

Grønbjerg, K. A., \& Paarlberg, L. (2001). Community Variations in the Size and Scope of the Nonprofit Sector: Theory and Preliminary Findings. Nonprofit and Voluntary Sector Quarterly, 30(4), pp. 684-706. doi: 10.1177 / 0899764001304004.

Hall, P. D., O’Neill, M., Vinokur-Kaplan, D., Young, D. R., \& Lane, F. S. (2001). Panel discussion: Where you stand depends on where you sit: The implications of organizational location for 
university-based programs in nonprofit management. Public Performance \& Management Review, 25(1), 74-87.

Halme, M., \& Laurila, J. (2009). Philanthropy, integration or innovation? Exploring the financial and societal outcomes of different types of corporate responsibility. Journal of business ethics, 84(3), 325-339.

Hansmann, H. B. (1980). The role of nonprofit enterprise. The Yale law journal , 89(5), pp. 835-901.

Hart, S. L., \& Milstein, M. B. (1999). Global sustainability and the creative destruction of industries. MIT Sloan Management Review, 41(1), 23.

Houston, D. J. (2006). Walking the Walk of Public Service Motivation: Public Employees and Charitable Gifts of Time, Blood, and Money. Journal of Public Administration Research and Theory, 16(1), pp. 67-86, https://doi.org/10.10.

Hwang, Hokyu, and Walter W. Powell. "The rationalization of charity: The influences of professionalism in the nonprofit sector." Administrative science quarterly 54.2 (2009): 268-298.

Kang, C., Huh, S., Cho, S., \& Auh, E. Y. ( de 2015). Turnover and retention in nonprofit employment: The Korean college graduates' experience. Nonprofit and Voluntary Sector Quarterly, 44(4), pp. 641-664.

Kaplan, R. S. (2001). Strategic performance measurement and management in nonprofit organizations. Nonprofit management and Leadership, 11(3), pp. 353-370. https://doi.org/10.1002/nml.11308.

Kohli, A. K., \& Jaworski, B. J. (1990). Market orientation: the construct, research propositions, and managerial implications. Journal of marketing, 54(2), pp. 1-18.

Kong, E. (2007). The strategic importance of intellectual capital in the non-profit sector. Journal of Intellectual Capital, 8(4 ), pp. 721-731. https://doi.org/10.1108/14691930710830864.

Kong, E. (2008). The development of strategic management in the non-profit context: Intellectual capital in social service non-profit organizations. International Journal of Management Reviews, 10(3), pp. 281-299. doi: 10.1111/j.1468-2370.2007.00224.x

Lee, Y. J. (2016). Comparison of job satisfaction between nonprofit and public employees. Nonprofit and Voluntary Sector Quarterly, 45(2), 295-313.

Liu, Chen, Pongsun Bunditsakulchai, and Qiannan Zhuo. 2021. "Impact of COVID-19 on Food and Plastic Waste Generated by Consumers in Bangkok" Sustainability 13, no. 16: 8988. https://doi.org/10.3390/su13168988

Lovelock, C. H., \& Weinberg, C. B. (1984). Marketing for Public and Nonprofit Managers. Wiley.

Mahmoud, M. A., \& Yusif, B. (2012). Market orientation, learning orientation, and the performance of nonprofit organisations (NPOs). International Journal of Productivity and Performance Management, 61(6), pp. 624-652.

Marques, R.P., Santos, C. \& Duarte, R. 2019. “A Web Platform on a Multi-tenant SaaS Architecture to promote the Accountability of the Social Economy Sector.” In CAPSI, 2019.

McDougle, L., McDonald, D., Li, H., McIntyre Miller, W., \& Xu, C. (2017). Can philanthropy be taught?. Nonprofit and Voluntary Sector Quarterly, 46(2), 330-351.

Mouritsen, J., Larsen, H. T., \& Bukh, P. N. (2005). Dealing with the knowledge economy: intellectual capital versus balanced scorecard. Journal of intellectual capital, 6(1), pp. 8-27. https://doi.org/10.1108/14691930510574636 .

Never, B. (2011). Understanding constraints on nonprofit leadership tactics in times of recession. Nonprofit and Voluntary Sector Quarterly, 40(6), 990-1004.

Rondinelli, D. A., \& London, T. (2003). How corporations and environmental groups cooperate: Assessing cross-sector alliances and collaborations. Academy of Management Perspectives, 17(1), pp. 61-76.

Rotheroe, N. and Richards, A. 2007. "Social Return on Investment and social enterprise: Transparent accountability for sustainable development." Social Enterprise Journal, 3(1), 31-48.

Rose-Ackerman, S. (1996). Altruism, nonprofits, and economic theory. Journal of economic literature, 34(2), 701-728.

Salamon, L. M. (1987). Of market failure, voluntary failure, and third-party government: Toward a theory of government-nonprofit relations in the modern welfare state. Journal of voluntary action research, 16(1-2), pp. 29-49. 
Salamon, L. M., \& Geller, S. L. (2007). The nonprofit workforce crisis: Real or imagined? Baltimore, MD: Center for Civil Society Studies Institute for Policy Studies, Johns Hopkins University: Communiqué No. 8.

Sanford, C. 2011. "The responsible business: reimagining sustainability and success." s.1.:John Wiley and Sons.

Sangole, N., Kaaria, S., Njuki, J., Lewa, K., and Mapila, M. 2014. "Community based participatory monitoring and evaluation: Impacts on farmer organization functioning, social capital and accountability." The Journal of Rural and Community Development, 9(2), 128-148.

Santos, C., Ferreira, A. D., Marques, R. P., Azevedo, G. M., \& Inácio, H. 2019. "Modernization and Accountability in the Social Economy: A Systematic Review." In A. Ferreira, R. Marques, G. Azevedo, H. Inácio, \& C. Santos (Eds.), Modernization and Accountability in the Social Economy

Saxton, G. D., \& Benson, M. A. (2005). Social capital and the growth of the nonprofit sector. Social Science Quarterly, 86(1), pp. 16-35.

Schepers, C., De Gieter, S., Pepermans, R., Du Bois, C., Caers, R., \& Jegers, M. (2005). How are employees of the nonprofit sector motivated? A research need. Nonprofit Management and Leadership, 16(2), 191-208.

Selsky, J. W., \& Parker, B. (2005). Cross-sector partnerships to address social issues: Challenges to theory and practice. Journal of management, 31(6), 849-873.

Simmons, W. O., \& Emanuele, R. (2010). Are volunteers substitute for paid labor in nonprofit organizations? Journal of Economics and Business, 62(1), 65-77.

Steinberg, R., \& Gray, B. H. (1993). The Role of Nonprofit Enterprise" in 1993: Hansmann Revisited. Nonprofit and Voluntary Sector Quarterly, 22(4), pp. 297-316.

Stewart, T. A. (1997). Intellectual Capital: The New Wealth of Organisations. Currency Doubleday, New York, NY.

Tomé, B., Bandeira, A.M., Azevedo, G. \& Costa, A. 2019. "Sustainability and Corporate Social Responsibility in the perspective of social economy entities: a bibliometric study." In 18th International Conference on Corporate Social Responsibility (CSR) and 9th Organizational Governance Conference. Escola Superior de Gestão do IPCA (Barcelos), julho.2019.

Tomé, B., Meira, D., Bandeira, A.M. 2016. "Os desafios das cooperativas de solidariedade social portuguesas face ao novo Estatuto das Instituições Particulares de Solidariedade Social.” In XVI Congreso de Investigadores en Economia Social de Ciriec España - Valencia, outubro, 2016.

Twombly, E. (2003). What Factors Affect the Entry and Exit of Nonprofit Human Service Organizations in Metropolitan Areas? Nonprofit and Voluntary Sector Quartery, 32, pp. 211-235.

Zainon et al. 2014a). "Legitimacy and sustainability of social enterprise: governance and accountability." Procedia - Social and behavioral sciences, 145, 152-157.

Zainon et al. 2014b). "An Integrated Ritual Effectiveness Accountability Reporting System (i-REARs) for Non-Profit Organizations.” International Business Research, 7(5), 156-165. 


\section{Anexo}

\section{Dimension 1. Purpose}

\begin{tabular}{|c|c|c|c|c|c|}
\hline Sub-dimension & & Indicator & Objective & $\begin{array}{l}\text { Reference } \\
\text { GRI 4, }\end{array}$ & Other References \\
\hline \multirow{7}{*}{ 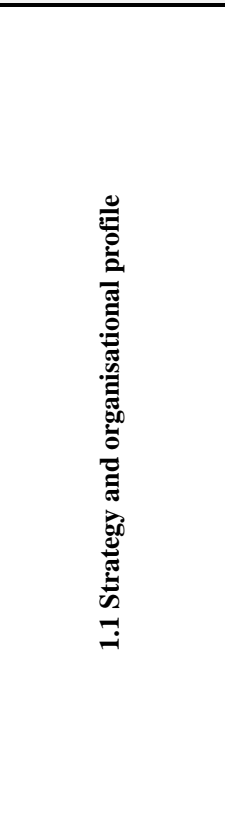 } & \multirow[t]{2}{*}{ AP } & Strategic Maturity of the Entity & $\begin{array}{c}\text { Identify the percentage of activities carried out as } \\
\text { main activities in relation to the possible main } \\
\text { activities }\end{array}$ & G4-4 & $\begin{array}{l}\text { Bartlett \& Ghoshal (1994); Hall \& O'Dwyer (2017); } \\
\text { MSESS (2014); Young (2001a; 2001b) }\end{array}$ \\
\hline & & Instrumental Activities & $\begin{array}{c}\text { Identify the exercise of another activity in addition } \\
\text { to the main activity }\end{array}$ & G4-4 & $\begin{array}{l}\text { Bartlett \& Ghoshal (1994); Hall \& O'Dwyer (2017); } \\
\text { MSESS (2014); Zainon, et al. (2014); Young (2001a; } \\
\text { 2001b); Albert \& Whetten (1985) }\end{array}$ \\
\hline & EPE & Existence of a Strategic Plan & Assess the existence of a strategic plan & G4-1 & $\begin{array}{l}\text { Al-Tabbaa (2012); Claeyé \& Jackson (2012); Hitt, } \\
\text { Ireland, \& Hoskisson (2012); Moore (2000); Bryce } \\
\text { (2017); Hall \& O'Dwyer (2017); Werther \& Berman } \\
\text { (2001); Young (2001b) }\end{array}$ \\
\hline & MEE & Strategic Maturity of the Entity & Assessing strategic maturity & G4-42 & $\begin{array}{l}\text { Allison \& Kaye (2015); Bryce (2017); Bryson (2018); } \\
\text { Drucker (1973); Hall \& O'Dwyer (2017); Hitt, Ireland, \& } \\
\text { Hoskisson (2012); Kaplan (2001); Moore (2000); Oliveira } \\
\text { (2010); Werther \& Berman (2001); Young (2001a, 2001b) }\end{array}$ \\
\hline & SGQ & Quality Management System & $\begin{array}{l}\text { Gauging the concern with the quality of the } \\
\text { services provided }\end{array}$ & G4-45 & $\begin{array}{l}\text { (Al-Tabbaa, Gadd, \& Ankrah, 2013; Cairns, Harris, } \\
\text { Hutchison, \& Tricker, 2005) }\end{array}$ \\
\hline & MAD & Performance Evaluation Models & $\begin{array}{l}\text { Assess the existence of organizational global } \\
\text { performance evaluation models }\end{array}$ & G4-45 & $\begin{array}{l}\text { Cairns, Harris, Hutchison, \& Tricker (2005); Kaplan } \\
\text { (2001); Kong (2008); Medina-Borja \& Triantis (2014); } \\
\text { Rees (1998); Bou-Llusar, Escrig-Tena, Roca-Puig \& } \\
\text { Inmaculada (2005); Shields et al. (2005); Becker, Antuar } \\
\text { \& Everett (2011); Cheverton (2007) }\end{array}$ \\
\hline & MDF & Job Description Manual & Evaluate the existence of a job description manual & G4-45 & $\begin{array}{l}\text { (Bou-Llusar, Escrig-Tena, Roca-Puig, \& Inmaculada, } \\
\text { 2005) }\end{array}$ \\
\hline \multirow{3}{*}{ 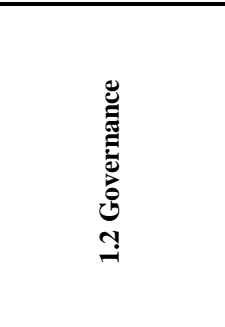 } & PTOS & $\begin{array}{l}\text { Employees' Participation on Governing } \\
\text { Bodies }\end{array}$ & $\begin{array}{l}\text { To assess the democratic nature and/or } \\
\text { heterogeneity of the entity's governing bodies }\end{array}$ & G4-38 & $\begin{array}{l}\text { Campbell \& Alexander (1997); Freeman (1999); } \\
\text { Friedman (1970); Hitt, Ireland, \& Hoskisson (2012); } \\
\text { Ireland \& Hitt (1999); Kaplan (2001); Kleinknecht } \\
\text { (2015); MSESS (2014); Porta et al. (1998) }\end{array}$ \\
\hline & $\begin{array}{l}\text { PMHO } \\
\text { S }\end{array}$ & $\begin{array}{l}\text { Parity between men and women on } \\
\text { governing bodies }\end{array}$ & $\begin{array}{c}\text { Gauging the concern with the balance between } \\
\text { leadership profiles }(M / W)\end{array}$ & G4-38 & $\begin{array}{l}\text { Branson, Chen, \& Redenbaugh (2013); Lewis, Edwards, } \\
\text { Lewis, B., \& McGinnis (2013); Themudo (2009); Pynes } \\
(2000)\end{array}$ \\
\hline & $\begin{array}{l}\text { PROSR } \\
\text { P }\end{array}$ & $\begin{array}{l}\text { Weight of Governing Bodies Remuneration } \\
\text { in Staff Remuneration }\end{array}$ & $\begin{array}{l}\text { Assessing the balance of compensation of the } \\
\text { responsibilities assumed }\end{array}$ & G4-54 & $\begin{array}{l}\text { Kaplan (2001); Rassart \& Miller (2013); Spear (2004); } \\
\text { Wolf \& Mair (2019); MSESS (2014) }\end{array}$ \\
\hline 1.3 Transparency & $\mathrm{TE}$ & Transparency & Assess the transparency of the entity & G4-56 & $\begin{array}{l}\text { Bagnoli \& Megali (2011); Pointer \& Orlikoff (2002); } \\
\text { Cabedo, Fuertes-Fuertes, Maset-LLaudes, \& Tirado- }\end{array}$ \\
\hline
\end{tabular}




\begin{tabular}{|l|l|r|l|l|l|}
\hline Sub-dimension & \multicolumn{2}{|c|}{ Indicator } & Objective & $\begin{array}{c}\text { Reference } \\
\text { GRI 4, } \\
\text { 2013 }\end{array}$ & Other References \\
\hline & & & & & $\begin{array}{l}\text { Beltrán (2018); Santos, Ferreira, Marques, \& do Carmo } \\
\text { Azevedo (2018) }\end{array}$ \\
\hline
\end{tabular}




\section{Dimension 2. Partners}

\begin{tabular}{|c|c|c|c|c|c|}
\hline Sub-dimension & \multicolumn{2}{|r|}{ Indicator } & Objective & $\begin{array}{l}\text { Reference } \\
\text { GRI 4, } 2013\end{array}$ & Other References \\
\hline \multirow{3}{*}{ 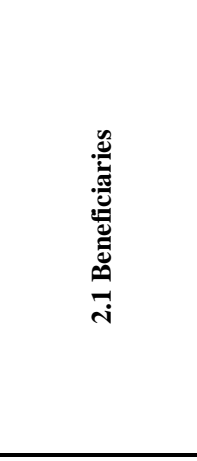 } & USE & $\begin{array}{l}\text { Users served by the entity in relation to the } \\
\text { demand for the social response }\end{array}$ & $\begin{array}{l}\text { Assess whether the entity is able to respond to the } \\
\text { needs of the population }\end{array}$ & G4-24 & $\begin{array}{l}\text { Gibbons \& Jacob, 2018; Kaplan (2001); Lovelock \& } \\
\text { Weinberg (1984); Kaplan (2001); Gronbjerg \& Paarlberg } \\
\text { (2001)_Brooks (2003); Gronbjerg \& Paarlberg (2001); } \\
\text { Salamon (1987); Hansmann (1980); Steinberg \& Gray } \\
\text { (1993); Corbin (1999) Twombly (2003); Bielefeld } \\
\text { (2000); Saxton \& Bexton (2005) }\end{array}$ \\
\hline & MSU & Monitoring users' satisfaction & Evaluate the level of user satisfaction & $\begin{array}{l}\text { G4-PR5 } \\
\text { G4-PR5 }\end{array}$ & $\begin{array}{l}\text { Gibbons \& Jacob, 2018; Kohli \& Jaworski (1990); } \\
\text { Mahmoud \& Yusif (2012); Curi (2007); Grönroos } \\
\text { (2007); Grönroos \& Ravald (2011); Vargo, Maglio \& } \\
\text { Akaka (2008) }\end{array}$ \\
\hline & $\begin{array}{l}\text { MTRS } \\
\text { EU }\end{array}$ & $\begin{array}{l}\text { Monitoring the handling of } \\
\text { complaints/suggestions/compliments from } \\
\text { users }\end{array}$ & $\begin{array}{l}\text { Assess the entity's willingness to deal with } \\
\text { complaints and/or suggestions from users }\end{array}$ & - & $\begin{array}{l}\text { Gibbons \& Jacob, 2018; Kohli \& Jaworski (1990); } \\
\text { Mahmoud \& Yusif (2012); Curi (2007); Grönroos } \\
\text { (2007); Grönroos \& Ravald (2011); Vargo, Maglio \& } \\
\text { Akaka (2008) }\end{array}$ \\
\hline \multirow{7}{*}{ 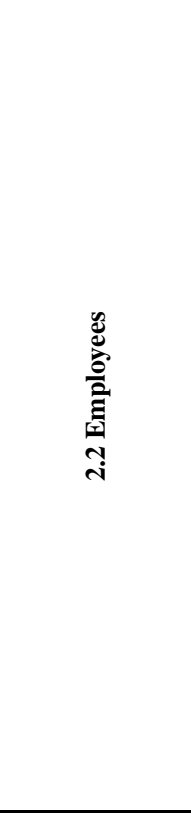 } & RRT & Carrying out meetings with the employees & $\begin{array}{l}\text { Assess whether the entity promotes the } \\
\text { participation and integration of employees }\end{array}$ & G4-LA4 & $\begin{array}{l}\text { Becker, Antuar \& Everett, C. (2011); Gibbons \& Jacob, } \\
\text { 2018; Kaplan (2001) }\end{array}$ \\
\hline & RE & Job turnover & $\begin{array}{c}\text { Assessing whether the entity provides lasting } \\
\text { employment }\end{array}$ & G4-LA1 & $\begin{array}{l}\text { Ban, Drahnak- } \\
\text { Faller \& Towers (2003); Salamon \& Geller (2007); Geurt } \\
\text { s, Schaufeli \& Jonge (1998); } \\
\text { Kang, Huh, Cho \& Auh (2015); Houston (2006) }\end{array}$ \\
\hline & RMEI & Use of inclusive employment measures & $\begin{array}{c}\text { Assess whether the entity is concerned with social } \\
\text { inclusion }\end{array}$ & - & $\begin{array}{l}\text { Becker, Antuar \& Everett (2011); Gibbons \& Jacob, } \\
2018\end{array}$ \\
\hline & TFSAF & $\begin{array}{l}\text { Employees with higher education who work } \\
\text { in their field of expertise in relation to the } \\
\text { total number of employees }\end{array}$ & $\begin{array}{l}\text { Evaluate the adequacy of the training profile to the } \\
\text { activities developed }\end{array}$ & - & $\begin{array}{l}\text { Kong (2007); Alvarez-González et al. (2017); } \\
\text { Stewart (1997); Moristsen, Larsen \& Bukh (2005); Kong } \\
\text { (2008); Fletcher et al. (2003); Hwang \& Powel (2009); } \\
\text { Austin et al. (2011); Ban et al. (2003) }\end{array}$ \\
\hline & TAIF & $\begin{array}{l}\text { Employees who attended } \\
\text { information/training sessions }\end{array}$ & $\begin{array}{l}\text { Gauging the entity's concern with the professional } \\
\text { enhancement of its employees through planned } \\
\text { information and professional training actions }\end{array}$ & \multirow[t]{2}{*}{ G4-LA11 } & \multirow{2}{*}{$\begin{array}{l}\text { Becker, K., Antuar, N., \& Everett, C. (2011); Gibbons \& } \\
\text { Jacob, 2018; Brown (2007); Connoly \& York (2002)); } \\
\text { Akingbola (2006); Chang, Huang \& Kuo (2015); Botins et } \\
\text { al. (2018); Carvalho, Melo \& Ferreira (2016). } \\
\text { Becker, Antuar, \& Everett (2011); Gibbons \& Jacob, } \\
\text { 2018; Brown (2007); Connoly \& York (2002)); Akingbola } \\
\text { (2006); Chang, Huang \& Kuo (2015); Botins et al. (2018); } \\
\text { Carvalho, Melo \& Ferreira (2016). }\end{array}$} \\
\hline & HAIFT & $\begin{array}{l}\text { Average number of hours of employee } \\
\text { information/training actions }\end{array}$ & $\begin{array}{l}\text { Gauging the entity's concern with the professional } \\
\text { enhancement of its employees through planned } \\
\text { information and professional training actions }\end{array}$ & & \\
\hline & MST & Monitoring employees' satisfaction & $\begin{array}{l}\text { Gauging the concern of the entity with the } \\
\text { satisfaction of the employees }\end{array}$ & G4-LA16 & $\begin{array}{l}\text { Becker, Antuar \& Everett (2011); Bathi \& Manimala } \\
\text { (2011); Scheper et al. (2005); Lee (2016); Cole et al. } \\
\text { (2002); Akingbola \& van den Berg (2019). }\end{array}$ \\
\hline
\end{tabular}




\begin{tabular}{|c|c|c|c|c|c|}
\hline \multirow[t]{2}{*}{ Sub-dimension } & \multicolumn{2}{|r|}{ Indicator } & Objective & $\begin{array}{c}\text { Reference } \\
\text { GRI 4,2013 }\end{array}$ & Other References \\
\hline & $\begin{array}{l}\text { MTRS } \\
\text { ET }\end{array}$ & $\begin{array}{l}\text { Monitoring the handling of employees' } \\
\text { complaints/suggestions/compliments }\end{array}$ & $\begin{array}{l}\text { Assess the sensitivity of the entity to deal with } \\
\text { employees' complaints/suggestions }\end{array}$ & G4-LA16 & $\begin{array}{l}\text { Becker, Antuar \& Everett (2011); Bathi \& Manimala } \\
\text { (2011); Scheper et al. (2005); Lee (2016); Cole et al. } \\
\text { (2002); Akingbola \& van den Berg (2019). }\end{array}$ \\
\hline \multirow{4}{*}{ 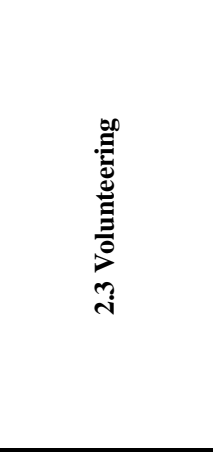 } & $\mathrm{CV}$ & Volunteer recruitment & $\begin{array}{l}\text { Assess the entity's capacity to attract new } \\
\text { volunteers }\end{array}$ & - & Simmons \& Emanuele (2010); Rose-Ackerman (1996) \\
\hline & TTV & Rate of voluntary work & $\begin{array}{l}\text { Assess the amount of work that is done by } \\
\text { volunteers }\end{array}$ & - & Simmons \& Emanuele (2010); Rose-Ackerman (1996) \\
\hline & HAIFV & $\begin{array}{l}\text { Average Number of Hours of } \\
\text { Information/Training for Volunteers }\end{array}$ & $\begin{array}{l}\text { Assess the entity's concern with valuing volunteers } \\
\text { through programmed information and professional } \\
\text { training actions }\end{array}$ & - & $\begin{array}{l}\text { Becker, Antuar \& Everett (2011); Gibbons \& Jacob, } \\
\text { 2018; Brown (2007); Connoly \& York (2002)); Akingbola } \\
\text { (2006); Chang, Huang \& Kuo (2015); Botins et al. (2018); } \\
\text { Carvalho, Melo \& Ferreira (2016). }\end{array}$ \\
\hline & VAIF & $\begin{array}{l}\text { Volunteers who attend information/training } \\
\text { sessions }\end{array}$ & $\begin{array}{l}\text { Assess the entity's concern with valuing volunteers } \\
\text { through programmed information/training actions }\end{array}$ & - & $\begin{array}{l}\text { Becker, Antuar \& Everett (2011); Gibbons \& Jacob, } \\
\text { 2018; Brown (2007); Connoly \& York (2002)); Akingbola } \\
\text { (2006); Chang, Huang \& Kuo (2015); Botins et al. (2018); } \\
\text { Carvalho, Melo \& Ferreira (2016). }\end{array}$ \\
\hline 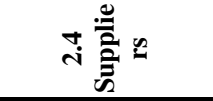 & CFL & Purchases from Local Suppliers & Assess the entity's concern with local economy & G4-EC9 & Bagnoli \& Megali (2011); Blecken et al. (2009) \\
\hline 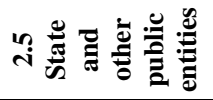 & $\mathrm{AP} \underline{a}$ & Partnership agreements & $\begin{array}{l}\text { Evaluate the capacity of the entity to relate to } \\
\text { other entities, benefiting its activity }\end{array}$ & G4-24 & $\begin{array}{ll}\text { Selsky \& } & \text { Parker } \\
\text { (2005); Never (2011); Halme \& Laurila (2009) } & \end{array}$ \\
\hline
\end{tabular}




\section{Dimension 3. Performance}

\begin{tabular}{|c|c|c|c|c|c|}
\hline Sub-dimension & & Indicator & Objective & $\begin{array}{l}\text { Reference } \\
\text { GRI 4, } 2013\end{array}$ & Other References \\
\hline \multirow{8}{*}{$\frac{\sum_{e}}{\sum_{n}}$} & FE & State Funding towards Total Funding & Assess the entity's dependence on state funding & G4-EC4 & - \\
\hline & FPS & $\begin{array}{l}\text { Service Provision Financing as a percentage } \\
\text { of Total Financing }\end{array}$ & $\begin{array}{l}\text { Assess the dependence of the entity on payments } \\
\text { from services provided }\end{array}$ & G4-EC1 & - \\
\hline & FIS & $\begin{array}{l}\text { Financing of Social Investment in relation to } \\
\text { Total Financing }\end{array}$ & $\begin{array}{c}\text { Assess the dependence of the entity on social } \\
\text { investment }\end{array}$ & G4-EC1 & - \\
\hline & FMD & $\begin{array}{l}\text { Patronage and Donations as a proportion of } \\
\text { Total Funding }\end{array}$ & $\begin{array}{c}\text { Assess the entity's dependence on patronage and } \\
\text { donations }\end{array}$ & G4-EC1 & - \\
\hline & FDE & $\begin{array}{l}\text { Non-monetary donations as a proportion of } \\
\text { Total Funding }\end{array}$ & $\begin{array}{l}\text { Assess the entity's reliance on non-monetary } \\
\text { donations }\end{array}$ & G4-EC1 & - \\
\hline & GFSE & $\begin{array}{l}\text { Expenditure on Supplies and External } \\
\text { Services against Operating Expenditure }\end{array}$ & $\begin{array}{l}\text { Assess the proportion of external supplies and } \\
\text { services in total expenditure }\end{array}$ & G4-EC1 & - \\
\hline & $\begin{array}{l}\text { GMVM } \\
\text { C }\end{array}$ & $\begin{array}{l}\text { Costs of Goods Sold and Consumed over } \\
\text { Operating Expenses }\end{array}$ & $\begin{array}{l}\text { Assess the proportion of costs of goods sold and } \\
\text { materials consumed in total costs }\end{array}$ & G4-EC1 & - \\
\hline & GP & $\begin{array}{l}\text { Personnel Expenses in relation to Operating } \\
\text { Expenses }\end{array}$ & $\begin{array}{l}\text { Evaluate the proportion of personnel expenditure in } \\
\text { total expenditure }\end{array}$ & G4-EC1 & - \\
\hline \multirow{3}{*}{ 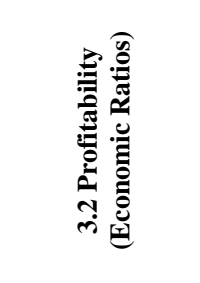 } & ROI & $\begin{array}{l}\text { Return on Investment (social investment, } \\
\text { State, patronage and donations) }\end{array}$ & $\begin{array}{l}\text { Assess the ability of the entity to create value from } \\
\text { the investments received }\end{array}$ & G4-EC1 & - \\
\hline & RFP & Return on Equity Funds & $\begin{array}{l}\text { Assess the ability to generate value from self- } \\
\text { financing }\end{array}$ & G4-EC1 & - \\
\hline & $\mathrm{VAB}$ & Gross Value Added & $\begin{array}{l}\text { Assess the entity's capacity to create value for the } \\
\text { different stakeholders }\end{array}$ & G4-EC1 & - \\
\hline \multirow{2}{*}{ 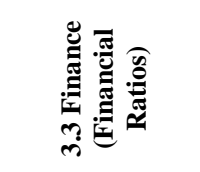 } & LG & General Liquidity & $\begin{array}{l}\text { Assess the ability of the entity to meet its short- } \\
\text { term financial commitments }\end{array}$ & G4-EC1 & - \\
\hline & FM & Working Capital & $\begin{array}{l}\text { Assess how the entity manages its exploitation } \\
\text { cycle }\end{array}$ & G4-EC1 & - \\
\hline
\end{tabular}




\section{Dimension 4. Proximity}

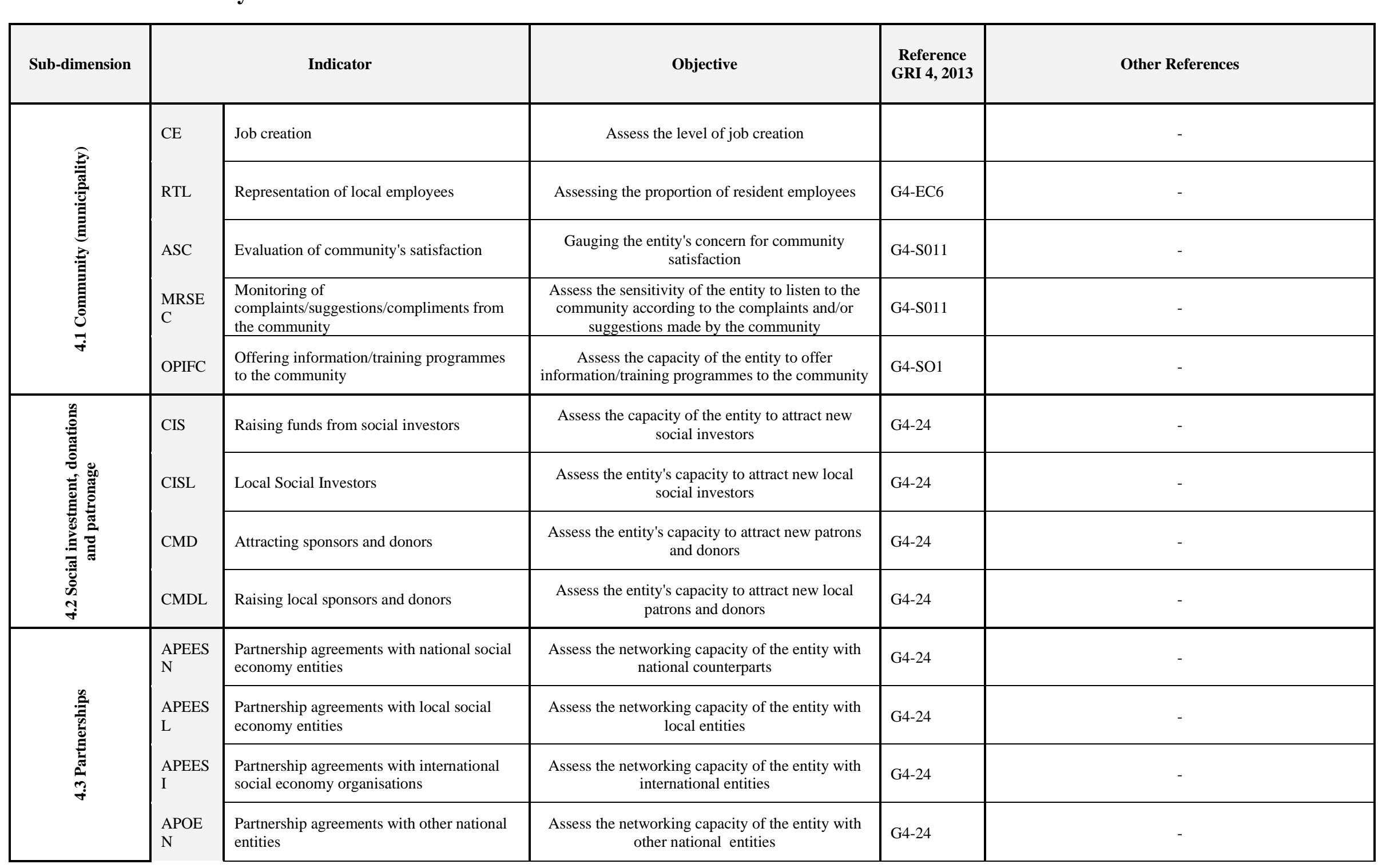




\begin{tabular}{|c|c|c|c|c|c|}
\hline Sub-dimension & & Indicator & Objective & $\begin{array}{l}\text { Reference } \\
\text { GRI 4, 2013 }\end{array}$ & Other References \\
\hline & & $\begin{array}{l}\text { Partnership agreements with other local } \\
\text { entities }\end{array}$ & $\begin{array}{l}\text { Assess the networking capacity of the organisation } \\
\text { with other local entities }\end{array}$ & G4-24 & - \\
\hline & APOEI & $\begin{array}{l}\text { Partnership agreements with other } \\
\text { international entities }\end{array}$ & $\begin{array}{l}\text { Assess the networking capacity of the entity with } \\
\text { other international entities }\end{array}$ & G4-24 & - \\
\hline & CEC & Attracting curricular internships & $\begin{array}{l}\text { Assess the ability to attract young students into } \\
\text { social work practice }\end{array}$ & - & - \\
\hline
\end{tabular}

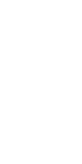

列
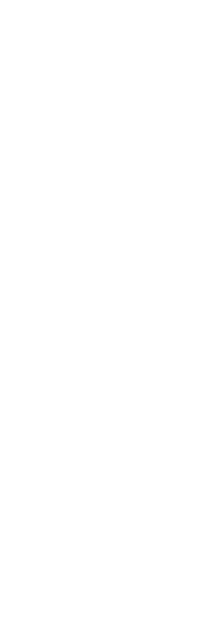

(




\section{Dimension 5. Planet}

\begin{tabular}{|c|c|c|c|c|c|}
\hline $\begin{array}{c}\text { Sub-dimension } \\
\\
\\
\end{array}$ & \multicolumn{2}{|r|}{ Indicator } & Objective & $\begin{array}{c}\text { Reference } \\
\text { GRI 4, 2013 }\end{array}$ & Other References \\
\hline \multirow{2}{*}{ 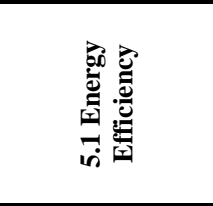 } & MEEn & Energy Efficiency Measures & $\begin{array}{l}\text { Assess the capacity to implement energy efficiency } \\
\text { measures }\end{array}$ & G4-EN6 & $\begin{array}{l}\text { Papaspyropoulos et al. (2012); Williams et al. } \\
\text { (2012); Rondinelli \& London } \\
\text { (2003) Crucke \& Decramer (2016) }\end{array}$ \\
\hline & MECA & Water Consumption Efficiency Measures & $\begin{array}{l}\text { Assess the concern with the implementation of } \\
\text { water consumption efficiency measures }\end{array}$ & G4-EN10 & $\begin{array}{l}\text { Papaspyropoulos et al. (2012); Williams et al. } \\
\text { (2012); Rondinelli \& London } \\
\text { (2003) Crucke \& Decramer (2016 }\end{array}$ \\
\hline \multirow{3}{*}{ 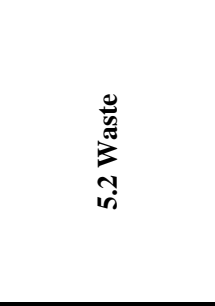 } & RSR & Selective Waste Collection & $\begin{array}{l}\text { Assess the concern with the implementation of } \\
\text { measures for selective waste collection }\end{array}$ & G4-EN 23 & $\begin{array}{l}\text { Papaspyropoulos et al. (2012); Williams et al. } \\
\text { (2012); Rondinelli \& London } \\
\text { (2003) Crucke \& Decramer (2017 }\end{array}$ \\
\hline & $\mathrm{RR}$ & Waste Reuse & $\begin{array}{c}\text { Gauging the concern with the implementation of } \\
\text { waste reuse measures }\end{array}$ & G4-EN 23 & $\begin{array}{l}\text { Papaspyropoulos et al. (2012); Williams et al. } \\
\text { (2012); Rondinelli \& London } \\
\text { (2003) Crucke \& Decramer (2016) }\end{array}$ \\
\hline & MR & Waste Mitigation & $\begin{array}{l}\text { Gauging concern about the implementation of } \\
\text { waste mitigation measures }\end{array}$ & G4-EN 23 & $\begin{array}{l}\text { Papaspyropoulos et al. (2012); Williams et al. } \\
\text { (2012); Rondinelli \& London } \\
\text { (2003) Crucke \& Decramer (2016) }\end{array}$ \\
\hline 5.3 Environment & $\mathrm{CA}$ & Environmental Awareness & $\begin{array}{l}\text { Gauging the entity's concern with the } \\
\text { implementation of environmental awareness } \\
\text { measures }\end{array}$ & G4-EN 31 & - \\
\hline
\end{tabular}




\section{Dimension 6. Progress}

\begin{tabular}{|c|c|c|c|c|c|}
\hline Sub-dimension & & Indicator & Objective & $\begin{array}{c}\text { Reference } \\
\text { GRI 4, 2013 }\end{array}$ & Other References \\
\hline \multirow{3}{*}{ 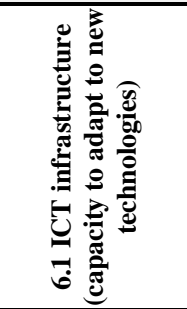 } & LI & Internet connection & $\begin{array}{l}\text { Gauging the entity's concern about the } \\
\text { implementation of measures for internet connection }\end{array}$ & - & - \\
\hline & LAN & Local Area Network & $\begin{array}{l}\text { Gauging the entity's concern for the } \\
\text { implementation of a local area network }\end{array}$ & - & - \\
\hline & VPN & Virtual Private Network & $\begin{array}{l}\text { Assess the entity's concern with the } \\
\text { implementation of a virtual private network access. }\end{array}$ & - & - \\
\hline \multirow{6}{*}{ 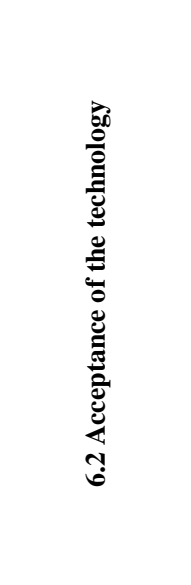 } & TICAS & ICT in Support Activities & $\begin{array}{c}\text { Assessing the entity's capacity to use ICTs in } \\
\text { support activities }\end{array}$ & - & - \\
\hline & TICAO & ICT in Operational Activities & $\begin{array}{l}\text { Assessing the entity's capacity to use ICTs in } \\
\text { operational activities }\end{array}$ & - & - \\
\hline & POTBS & $\begin{array}{l}\text { Online Platform for Goods and/or Services } \\
\text { Transaction }\end{array}$ & $\begin{array}{l}\text { Assess the entity's ability to use online platforms to } \\
\text { transact goods and/or services }\end{array}$ & - & - \\
\hline & \multirow{2}{*}{$\begin{array}{l}\text { POAIS } \\
\text { MD } \\
\text { FPUTI } \\
\text { C }\end{array}$} & $\begin{array}{l}\text { Online Platform for Raising Social } \\
\text { Investors, Sponsors and/or Donors }\end{array}$ & $\begin{array}{l}\text { Assess the entity's capacity to use online platforms } \\
\text { to raise social investors, sponsors and/or donors }\end{array}$ & - & - \\
\hline & & Facilitator in Promoting ICT Use & Evaluating the promotion of ICT use & - & - \\
\hline & FISTIC & $\begin{array}{l}\text { Facilitator in Interaction with Stakeholders } \\
\text { through ICTs }\end{array}$ & $\begin{array}{l}\text { Evaluate the capacity of interaction with } \\
\text { stakeholders through ICTs }\end{array}$ & - & - \\
\hline \multirow{2}{*}{ 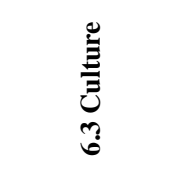 } & DICC & $\begin{array}{l}\text { Dissemination of the Community's Cultural } \\
\text { Identity }\end{array}$ & $\begin{array}{l}\text { Assess the entity's capacity to disseminate the } \\
\text { cultural identity of the community }\end{array}$ & - & - \\
\hline & PEITIC & $\begin{array}{l}\text { Promoting intergenerational experiences } \\
\text { through ICT }\end{array}$ & $\begin{array}{l}\text { Assessing the entity's capacity to promote } \\
\text { intergenerational experiences through ICTs }\end{array}$ & & \\
\hline
\end{tabular}


